\title{
Wearable Monitoring Devices for Biomechanical Risk Assessment at Work: Current Status and Future Challenges-A Systematic Review
}

\author{
Alberto Ranavolo ${ }^{1, *}$, Francesco Draicchio ${ }^{1}$, Tiwana Varrecchia ${ }^{2}$, Alessio Silvetti ${ }^{1}$ and \\ Sergio Iavicoli ${ }^{1}$ \\ 1 Department of Occupational and Environmental Medicine, Epidemiology and Hygiene, INAIL, \\ Via Fontana Candida 1, Monte Porzio Catone, 00078 Rome, Italy; f.draicchio@inail.it (F.D.); \\ al.silvetti@inail.it (A.S.); s.iavicoli@inail.it (S.I.) \\ 2 Department of Engineering, Roma TRE University, Via Vito Volterra 62, 00146 Rome, Italy; \\ tiwana.varrecchia@uniroma3.it \\ * Correspondence: a.ranavolo@inail.it
}

Received: 13 July 2018; Accepted: 11 September 2018; Published: 13 September 2018

\begin{abstract}
Background: In order to reduce the risk of work-related musculoskeletal disorders (WMSDs) several methods have been developed, accepted by the international literature and used in the workplace. The purpose of this systematic review was to describe recent implementations of wearable sensors for quantitative instrumental-based biomechanical risk assessments in prevention of WMSDs. Methods: Articles written until 7 May 2018 were selected from PubMed, Scopus, Google Scholar and Web of Science using specific keywords. Results: Instrumental approaches based on inertial measurement units and sEMG sensors have been used for direct evaluations to classify lifting tasks into low and high risk categories. Wearable sensors have also been used for direct instrumental evaluations in handling of low loads at high frequency activities by using the local myoelectric manifestation of muscle fatigue estimation. In the field of the rating of standard methods, on-body wireless sensors network-based approaches for real-time ergonomic assessment in industrial manufacturing have been proposed. Conclusions: Few studies foresee the use of wearable technologies for biomechanical risk assessment although the requirement to obtain increasingly quantitative evaluations, the recent miniaturization process and the need to follow a constantly evolving manual handling scenario is prompting their use.
\end{abstract}

Keywords: standardized biomechanical risk assessment methods; instrumental-based biomechanical risk assessment; wearable sensors; sEMG; IMUs; hand-held dynamometers; grip force sensors

\section{Background}

In recent years, wearable sensors have been used for quantitative instrumental-based biomechanical risk assessments in the prevention of work-related musculoskeletal disorders (WMSDs). Previously, in the attempt to reduce the risk of WMSDs while handling materials, handling people in the healthcare sector or while maintaining fixed postures, several methods have been developed, accepted by the international literature and used in the workplace. These approaches have without doubt facilitated prevention activities during the last decades by improving occupational health and safety of people at work but, on the other hand, need a significant update based on two main aspects. First, the standardized methods commonly used for biomechanical risk assessment are still mainly based on observational and subjective approaches [1-4] and don't include instrumentation-based tools. Second, the recent widespread use of robots, automation and mechanization in industry for the reduction of the physical effort has modified manual handling work activities. One of the key technologies 
driving this epochal change, the human-robot collaboration (HRC) technology $[5,6]$, is invading several areas of the industry and small-medium enterprises. The nascent nature of HRC in the workplace conceives the safe coexistence and interaction of workers and robots within the same environment allowing a significant transformation of the current static automation paradigms into adaptive, flexible and reconfigurable ones. In particular, the presence of the most advanced remotely controlled robot, occupational collaborative robots [7] and wearable trunk and upper-limb exoskeletons [8-12] will assist more and more workers in performing their tasks reducing their exposure to the associated physical demands.

In view of this new workplace setup there are some questions to ask: are the standardized biomechanical risk assessment methods able to take into account all these new factors? Are the most recent electronic wearable technologies used for biomechanical risk assessment? And again, can they be considered the answer to the aforementioned advanced "Industry 4.0" manufacturing solutions? The authors of this review propose that while advances in wearable wireless sensor networking and ubiquitous computing have paved the way for new possibilities in sport performance measures [13-16] and clinical applications [17-20], today their potential for biomechanical risk assessment is still largely underexploited and the state of the art lags dramatically behind the expectations. The hypothesis underlying this review is that the most innovative wearable technologies and electronic smart devices such as smartphones and tablets may improve the biomechanical risk assessment by adapting it to all the work conditions and overcoming the limits of the current standardized methods. For instance, intelligent work environments $[21,22]$ may represent the new scenario in which smart wearable sensors with computational capabilities and network connection are sensitive, responsive, adaptive and transparent [23] to workers' movements allowing online, real-time monitoring of work activities.

Thus, these devices, without interfering with the typical movements performed by workers at the workplace thanks to the miniaturization process and wireless protocols, would allow the estimation of biomechanical risk in real-time providing a direct feedback to the end-user who would be constantly monitored directly at work. In this way, the workers could modify their movements during the execution of work tasks thereby reducing and preventing their exposure to the risk of WMSDs.

To shed light on this issue, the aim of this review was, through a literature research (Section 2), to describe recent implementations of wearable sensors for quantitative instrumental-based biomechanical risk assessments in the prevention of WMSDs. To do this, we have provided:

- A brief description of the WMSD problem and of some standardized methods used for biomechanical risk classification, with their respective strengths and weakness (Section 3.1).

- An explanation of how wearable sensors work and measurements are performed, with particular attention to inertial measurement units (IMUs), hand-held dynamometers and grip force devices, and surface electromyography (sEMG) sensors (Section 3.2).

- A description of quantitative instrumental-based biomechanical risk assessment methods, which have proved themselves significant for physicians, ergonomists and researchers. These proposed tools have been analyzed for: (i) direct instrumental evaluations [24-26] providing real-time measures of risk of exposure, requiring simple hardware setup and allowing easy analysis and interpretation of data by workers (Section 3.3); (ii) rating standard methods for biomechanical risk assessment (Section 3.4).

- Finally, a discussion covering current issues, future challenges and limitations is reported in Section 4.

\section{Materials and Methods}

\subsection{Variable of Interest}

The variable of interest in this systematic review [27] was "wearable technologies for quantitative biomechanical risk assessment in work activities (i.e., lifting tasks, pushing and pulling, repetitive 
work handling people manual tasks in an industrial environment) able to minimize the disturbance caused by instrumentation to the user".

\subsection{Literature Search Strategy}

The literature search was performed from date of inception until 1976 on the following selected databases: Scopus, Web of Science, PubMed and Google Scholar. Weekly updates were performed until 7 May 2018. The following keywords concerning wearable devices, biomechanical risk assessment and work activities, were identified and combined: instrumental-based biomechanical assessment methods, manual lifting, handling people, pushing and pulling, repetitive moments, wearable sensors/devices/technologies, movement analysis, kinematics, kinetics, sEMG, IMUs, hand-held dynamometers and grip force sensors.

Electronic searches were performed by one author (R.A.), who screened all potential titles, abstracts, and if needed, full-texts for eligibility. The reference lists of all the selected articles were also scanned to identify other eligible articles.

\subsection{Review Process}

The study was conducted using the systematic review method proposed by the Preferred Reporting Items for Systematic Reviews and Meta-Analysis (PRISMA), as shown in Figure 1. The search was limited to papers in journals, chapters of books and periodicals, conference proceedings and Ph.D. dissertations. For all the duration of the screening selections were based on the significance of the recognized articles regarding the matter of the review. Three independent reviewers (R.A., T.V. and A.S.) assessed titles and abstracts of the articles. The full text reading was done when titles and abstracts offered satisfactory information. Disagreements among reviewers were resolved by scheduling dedicated consensus meetings of all authors.

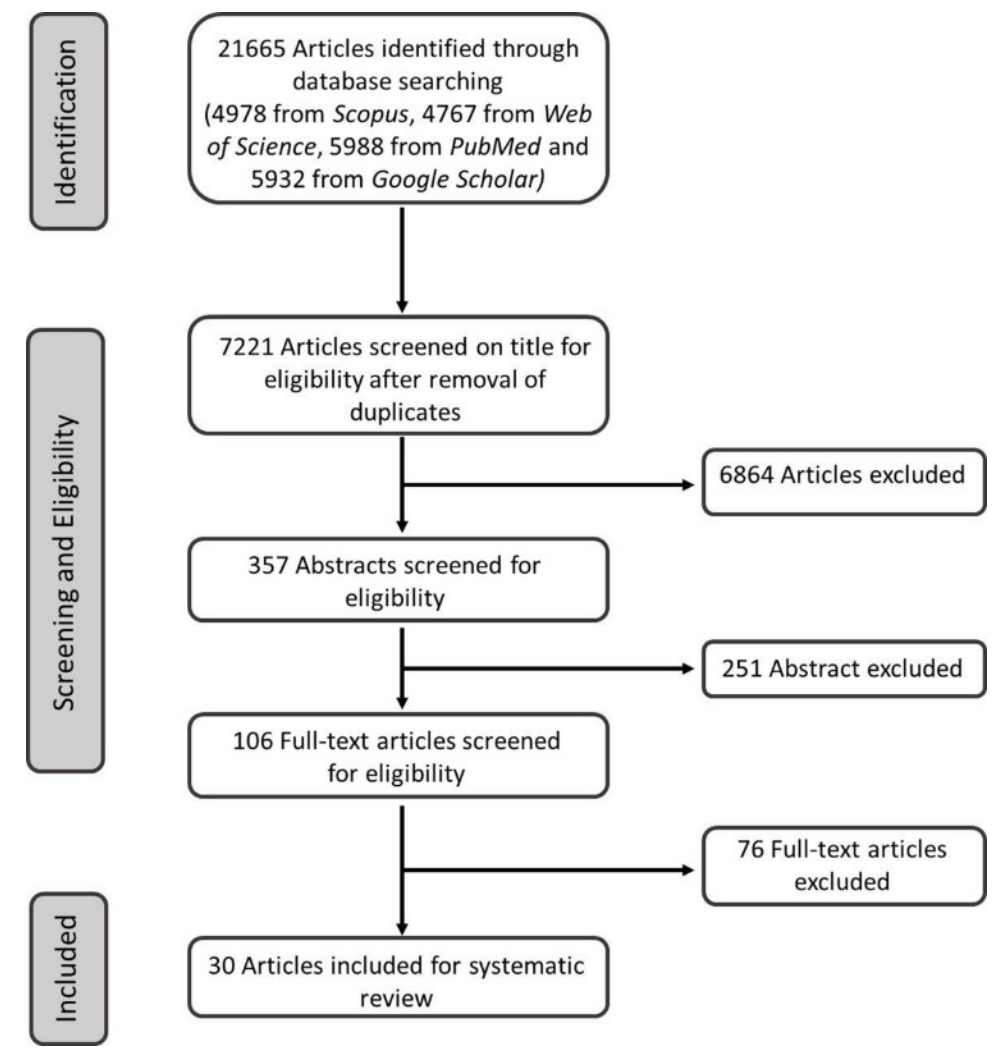

Figure 1. Flow-chart according to the different phases of the systematic review as proposed by PRISMA. 


\section{Results}

From the database search, after removing duplicates, 7221 references were retrieved and screened for eligibility based on their titles (Figure 1). Following that, 357 abstracts and 106 full text articles were assessed for eligibility. Articles were excluded due to the facts that wearable devices were not used in biomechanical risk assessment or they were not used in work activities, biomechanical risk assessment methods were not instrumental, there was no instrumental assessment of work activities, movement analysis (kinematics, kinetics, sEMG, IMUs, hand-held dynamometers and grip force sensors) was not in the work activities or instrumental approaches were not used. A total of 30 articles were finally included in this review.

\subsection{Work-Related Musculoskeletal Disorders (WMSDs)}

WMSDs are widespread in many jobs and a constantly growing concern for health and safety workers and for manufacturing system productivity [2,3]. The annual incidence of WMSDs in the industrialized world accounts from a third to a quarter of all occupational diseases, making these disorders the most expensive form of workplace disability [28-42].

Among WMSDs, work-related low-back disorders (WLBDs) and upper limb work-related musculoskeletal disorders (UL-WMSDs) are the most common, with a 12-month worldwide prevalence of almost $18 \%$ [43-51] and ranging from $12 \%$ to $41 \%$, respectively [52]. In particular, the proportion of the population exposed to ergonomic risk factors for WLBDs is $87 \%$ according to the Global Burden of Disease 2016 [53]. Furthermore, WMSDs account for $64 \%$ of the total number of reported occupational disorder cases [54].

WMSDs occur when the spinal load exceeds tissue tolerance [55,56], when the central nervous system co-activates antagonistic trunk muscles in the attempt to stabilize the trunk in presence of excessive external loads [57] or when the working tasks lead to local muscle fatigue [58-61]. For this reason, the relationship between manual handling tasks and musculoskeletal health is considered multifactorial [62] although task features, individual biomechanical and physiological factors accompanied by altered motor control mechanisms represent the main determinants [63]. Critical working tasks are predominantly manual lifting and patient handling, pushing and pulling and repetitive activities, awkward and/or sustained postures and prolonged sitting [50,64-76].

The international standards 11228-1, 2 and 3, 11226, TR 12295 and TR 12296 [77-82] accept and list the methods able to detect occupational physical risk factors and to evaluate the usefulness of ergonomic interventions. These methods consider several indices to be measured, from motion amplitude and frequency to exerted force [2].

The strength of these traditional approaches for biomechanical risk classification which can be used in a wide range of professional conditions, is based on their inexpensiveness and non- invasiveness. On the other hand, these methods have some weaknesses, mainly due by their observational nature and subjectivity related to the practitioner's expertise [1-4]. In most cases the worker's behavior is evaluated on pro-forma sheets either while observing in the field or replaying videos, an approach considered inaccurate, imprecise and time consuming $[2,83,84]$. Furthermore, the scientific literature highlights equations and parameter restrictions, with insufficient accuracy, unrepeatability and unreliability $[4,85,86]$. These concerns are mainly due to the necessity of assignment of scores to each risk determinant, such as upper and lower limb joint angles and range of motions, loads displacement, forces, work cycles, frequency of actions, forces and recovery times [85,87-94].

Accurate and precise results could be better achieved by means of modern measuring devices, facilitating experts' diagnostics [2]. In recent years, instrument-based techniques designed based on current technological advances and performing direct measurements by using sensors attached to workers' bodies have been developed (see Table 1) and are now able to capture some or all of the parameters needed in the computation of the risk level. These instrumental and quantitative sensor-based tools might greatly increase the accuracy of these methods in ways that were not previously available $[25,69,70,95]$ and widely reduce the time that an expert needs to carry out the same 
assessment manually. Finally, the use of automatic online tools would give a meaningful evaluation by gathering posture, kinematic, kinetic and muscular activity data in assessing WMSDs risk.

\subsection{IMUs, Hand-Held Dynamometers and Grip Force Devices, sEMG Sensors: How They Are Made and Measure}

Movement analysis systems allow, with a high accuracy and acquisition frequency, the quantification of motor functions, motor abilities, pathological conditions, compensatory motor strategies and improvements due to rehabilitation treatments and ergonomic interventions. However, these systems can be easily used only within the laboratory and more difficult in the field. This difficulty has led to the development, in the last decade, of accurate and reliable wearable human body sensor-based tools for easy human motion analysis directly in the workplace. The main factor allowing the abovementioned use has been, without doubt, the miniaturization of devices which has allowed huge benefits over traditional approaches. Other factors are wireless connectivity, light weight, small-size, low power consumption, portability, low-cost, comfort, and the possibility to monitor subjects remotely and to provide feedback to the end-user [19,96-102].

Among wearable human body sensors, inertial measurement units (IMUs), dynamometers and surface electromyography (sEMG) sensors (see Figure 2) allow a detailed estimation (compared to traditional observational methods) of kinematics, kinetics and muscle behaviors without interfering with the typical movements performed by workers in the workplace $[103,104]$.

A

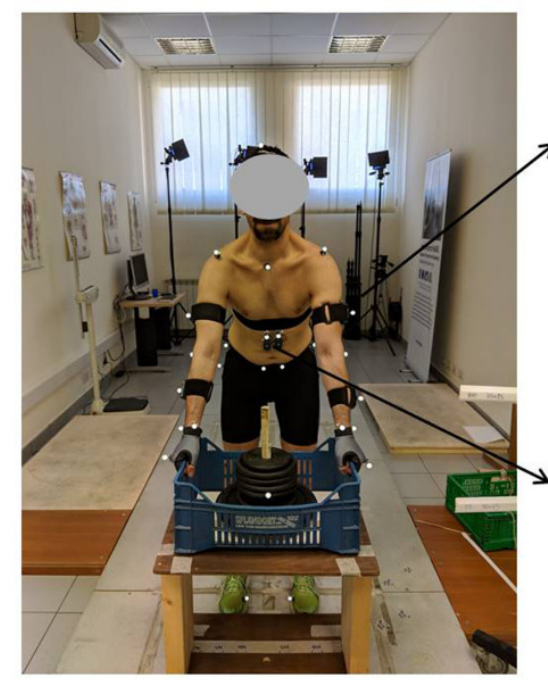

Inertial measurement units (IMUs)

\section{Dynamometer} sensors

\section{Surface}

electromyography

(sEMG) sensors

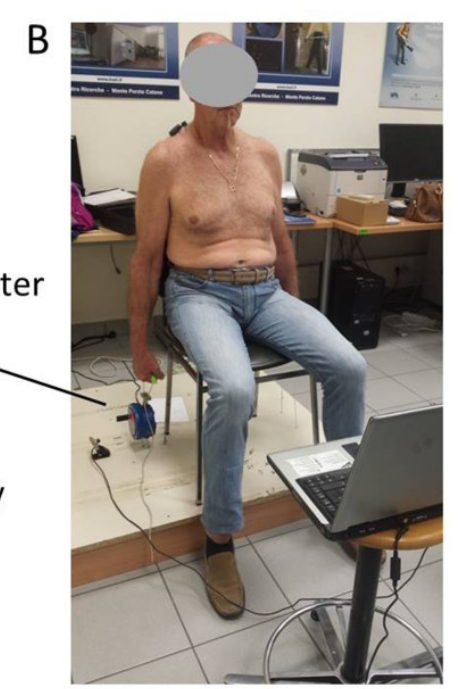

Figure 2. Sensors in ergonomics application: (A) Inertial measurement units (IMUs) and electromyography (sEMG) sensors used in lifting acitivities; (B) Dynamometer used before and after repetitive work.

In experimental settings, IMUs, dynamometers and sEMG sensors are placed and fixed on the appropriate body segments to measure joint angles, forces and muscle behaviors, respectively. All the sensors are commonly synchronized for data alignment in time [105]. Connection is always performed by implementing one of two wireless protocols: Wi-Fi or Bluetooth. The former has an increased power consumption, but a greater transmission speed and distance with respect to the latter. The sample frequency of these sensors varies between 50 and $1000 \mathrm{~Hz}$ while the minimum number of bit is 12 [106].

\subsubsection{IMUs}

IMUs allow the measure of orientation, position, velocity and accelerations of each investigated segment and whole body posture. The term "inertial" comes from the fact that these sensors use the inertia principle: the acceleration can be related to the resistance to move (inertia) of a free mass accelerated by an external force or torque. In the literature, the type of sensors used ranges from uniaxial to triaxial accelerometers, gyroscopes and magnetic sensors [99]. Usually three orthogonal accelerometers and three orthogonal gyroscopes are embedded within the probe to measure linear 
acceleration and angular velocity, respectively, along three orthogonal axes. Angular displacements are obtained from numerical integration of the angular velocity while linear velocity and displacement are estimated from first and second numerical integration of linear accelerations. IMUs can also embed tri-axial magnetic sensors although their use turns out to be more critical in the workplace in presence of electromagnetic fields.

\subsubsection{Hand-Held Dynamometers and Grip Force Sensors}

Hand-held dynamometers, already described at the beginning of the previous century [107], are simple devices placed between a fixed place and the subject's body part to assess the isometric muscle (or muscle group) strength relevant as outcome measurements in studies evaluating changes in the functional status of joints, lower and upper extremities and trunk [108-114]. These devices are considered highly reliable [115], easy to use, portable, inexpensive and compacts if compared with isokinetic systems [112]. Besides hand-held dynamometers, forces are also recorded by using superior grip dynamometers although they can only be used for given hand sizes. Other critical issues related to grip dynamometers are the inability to measure forces from multiple fingers simultaneously, difficulty of use, low accuracy of grip force measurements and the difficulty to design appropriate handle shapes [116-120]. The measure of the grip force is also provided by instrumented gloves (i.e., equipped by force sensitive resistors) or by force sensor mats applied to handles [73,121-126]. Instrumented gloves remove the need for the handle to be instrumented but disturb grasp interaction [127]. Furthermore, force sensor mats embedded within gloves acquire only normal forces, require calibration and may shift during measurements. In order to overcome these limitations multi-dimensional grip dynamometers have been developed to adapt to a wide variety of handle sizes and geometries allowing a continuous measure of fatigue and forces $[119,127,128]$. Recently dynamometers able to measure both angle and force with high levels of sensitivity and inter-examiner reliability have been developed [129-132]. Finally, it is interesting to also report haptic tools which consist of physical bendable strips allowing users to manipulate and apply deformations to digital surfaces and to move and rotate virtual objects. Such device allows a continuous, free hand contact on a developable strip bent allowing to industrial designers and stylists to perform an effective assessment of the aesthetic quality of the shape of new products and also its modification, directly on the digital prototype without the need to construct a physical prototype [133-135].

\subsection{3. sEMG Sensors}

sEMG provide the measure of electrical activity (on the skin) of the muscles involved in the movement. Single- or double differential bipolar sEMG performed by using wet electrodes is widely and easily used in ergonomics for research activities and directly at the workplace [136-141]. sEMG allows the calculation of a lot of parameters regarding muscle behavior such as, among other features, the "activation timing" [142-150], the amplitude (maximum values, average rectified values or ARVs, root mean square or RMS) $[137,146,151-155]$ and co-activations $[57,66,156]$. Multi-channel sEMG performed by means of linear and two-dimensional electrodes arrays (high-density sEMG) allows instead the estimation of the motor unit action potential analysis [157-161], the estimation of the local muscle fatigue (the myoelectric manifestation of muscle fatigue) $[60,138,162-167]$ and the analysis of the instantaneous potential maps [160]. In particular the local muscle fatigue is estimated by measuring the decrease in the fiber conduction velocity $[168,169]$ which imply a scaling of the sEMG signal power density towards the lower frequencies and an increase its amplitude [170-172].

\subsection{Direct Instrumental Evaluations}

In this section of the results we report papers whose aims were to propose instrumental-based tools for biomechanical risk classification without using measured/calculated indices as input to standardized methods. Instrumental approaches based on wearable sensors have been used to classify lifting tasks into low and high risk categories. In a very recent study [173], IMUs and sEMG 
sensors have been used to monitor trunk inclination and trapezius and erector spinae muscle activity, respectively, during the execution of several types of lifting tasks with different weights, horizontal distance and technique executed by male office workers. The method proposed in this study allows, with an acceptable accuracy, the automatic identification of the risk levels associated with the lifting activities. Indeed, the lifting tasks were characterised by a feature vector composed of either the 90th, 95th or 99th percentile of sEMG activity level and trunk inclinations during the task. Linear Discriminant Analysis and a subject-specific threshold scheme were applied and lifting tasks were classified. The authors of this study highlighted how the strength of this study lies on its objective instrumental approach based on subject-specific thresholds and on the possibility to complement the current standardized approaches usually used to detect biomechanical hazardous.

Another recent kinematic-based lifting tool has been designed by monitoring several lifting tasks with growing lifting index (LI) computed by the revised NIOSH lifting equation [174]. Kinematic data allowed the calculation of a mechanical lifting energy consumption (LEC) index which proved to be significantly growing with the LI, discriminating all the risk condition pairs and well correlating with compression and shear forces that determine injuries at the L5-S1 joint. The findings of this study suggest a potential use of IMUs-based lifting tools in indoor and outdoor work environments for risk estimation.

Furthermore, muscle coactivation has deeply been investigated [66] because it, being a neuromuscular pattern needed to stabilize the trunk [57], represents one of the causal pathways for WLBDs. The behavior of the cervical and lumbar spine has also been investigated in complex multiplanar dynamic motions including lifting and pushing $[175,176]$. sEMG has been used to develop a sEMG-based multi-muscle coactivation index that resulted usable to continuously assess the neuromuscular effort and significantly sensitive to several factors. In particular the higher the speed, complexity of the motion and head control are, the higher the coactivation index value is. Also, in this case this simple approach has been proposed to be used for ergonomic assessments.

Another tool developed to calculate the simultaneous activation of trunk muscles is the time-varying multi-muscle co-activation index (TMCi) which includes a sigmoid-weighting factor dependent on relative differences between muscles that do not rely on a priori definitions of agonist or antagonist behavior [156]. This index was evaluated during the execution of lifting task in controlled conditions considering trunk muscles [156]. It has been shown that heavier lifting conditions resulted in higher TMCi values and that significant correlations exist between the TMCi and other agonist-antagonist methods. The same experimental setup used for LEC calculation [174] allowed to understand that also simple sEMG parameter values (i.e., ARV and max), besides TMCi, increased under heavier lifting conditions [177].

Moreover, sEMG data were also used in a study to implement tools based on an artificial neural network [178]. In this study sEMG features (i.e., max, ARV, mean and median frequencies) were evaluated during the execution of lifting tasks starting from the trunk muscles. Then, these features were used as input variables of artificial neural network for the prediction of WLBDs. The results show that sEMG time and frequency features are significantly related to lifting index for specific trunk muscles. Furthermore, the findings show that a tool based on these machine-learning techniques and sEMG feature, choosing a proper combinations of input features and a right network architecture, can lead to an improved biomechanical risk classification. Moreover, the authors concluded that the possibility to implement the integrated approach on electronic smart devices (smartphones, phablets, tablets and smartwatches) would allow a simplified analysis of biomechanical risk at workplace.

Manual lifting has also been assessed by using muscle fatigue estimation. In a recent review regarding this issue a list of methods was given, though the authors concluded that there are still many gaps to be filled and further studies are needed to find better fatigue indices and improved techniques [179].

Besides lifting activities, wearable sensors have been used for direct instrumental evaluations in handling of low loads during high frequency activities. For instance, local myoelectric manifestation of muscle fatigue estimation $[160,161,180]$ has been estimated in several conditions to investigate several 
groups of workers. In particular it was used to investigate: (i) the biomechanical exposure of younger and older groups [181,182]; (ii) changes in fatigability in jobs with and without pause [166]; (iii) upper limb and trunk muscles in simulations of assembly tasks and in different light levels of repetitive work [162-165,167,182-185]. Further experiments have been designed and performed in a recent study of Ranavolo and colleagues [58] in which the association between the local elbow flexor muscles fatigue and physical demand has been investigated. The findings of this study showed that local muscle fatigue estimated by using miniaturized sEMG sensors placed on the brachioradialis muscle is a promising index because of its sensitivity to the risk classes. Kinematic and sEMG assessments have also been performed in biomechanical evaluation of supermarket cashiers before and after a redesign of the checkout counter, in analysis of post office employees' workstations and in manual handling on a supermarket greengrocery shelf [186-188].

Finally, the usefulness of wearable sensors has also been investigated in many work tasks which require intensive and repetitive production of forces on the upper extremities in manipulating external loads, wrists, palms, fingers and tendons [189-191]. In these cases, the role of wearable sensors, in most cases hand-held dynamometers devices, is to measure the normal and shear forces created between fingers and handles to assess muscle integrity and to determine the level of any strength deficits [192,193] associated to clinical physical examination tests (i.e., the diagnosis of shoulder pain [194]). A wearable, unobtrusive, wireless and accurate system (Activity Tracking with Body Area Network) has been designed to operate autonomously to quantitatively measure the postures and body motions of workers [2]. This system is meant to be used by workers to autonomously monitor themselves on actual job sites over long periods of time. Different working processes in a wood workshop have been evaluated by using three accelerometers and two microphones and by correlating the worker's motion and frequency and intensity of sounds [195]. IMUs were also used in several work activities such as car assembly, hammering, screwing and drilling [196,197]. In construction activities IMUs [198-200] and sEMG has been used to monitor lifting and holding loads activities to detect potential sources of WMSDs at neck [201] lower back levels [202].

\subsection{Risk Assessment in the Context of Rating of Standard Methods}

As done for direct instrumental evaluations, in this section tentative ratings of standard methods using wearable technologies are analyzed. An innovative "on-body wireless sensors network"-based approach for real-time ergonomic assessment in industrial manufacturing has been proposed by Vignais and colleagues [84]. The sensor network was composed by IMUs and goniometers and the body posture (joint angles) was assessed by using a ten rigid segment, twenty degrees of freedom biomechanical model. IMUs were placed bilaterally on the upper arm and forearms, on the head, trunk (on the chest) and pelvis (on the sacrum). Goniometers were placed on the hands and forearms to measure wrist motions. Angle values were used as input within the Rapid Upper Limb Assessment (RULA) method, whose global and local scores were continuously computed by a mobile processing unit (a standard laptop) and fed back to the user via a see-through head-mounted display.

Moreover, a real-time body sensors network composed by IMUs and sEMG sensors has also been used in real-time to monitor workers by measuring muscular efforts and postures (upper limbs have been modeled as a 7-DoF kinematic chain) for WMSD prevention according to the RULA index and the Strain Index (SI) [3]. An interesting index considered for this tool is the percentage of time spent in every RULA score range by every worker, considering the whole experiment duration. The accuracy, expressed as the number of correct assessments (with respect to those performed by two human evaluators) of the system and the number of cycles, was 95\% for RULA and $45 \%$ for SI, indicating that the body sensor network is able to give a RULA score estimation congruent to the one given by the human evaluators. As far as the SI score is concerned, the system gives a score congruent to the evaluators' evaluation in almost the $50 \%$ of the cases.

sEMG has also been used for complementing the RULA scoring system [203] and as an alternative to the visual inspection according to the BORG scale. It is in fact demonstrated that the two 
assessments are strongly correlated [87]. An example of the latter application has been studied by Cabeças [204] where sEMG was used as an alternative to observational methods in computing the SI score. The authors concluded that, once appropriate trigger levels for the muscular activation are defined, sEMG is a valid alternative to visual inspection in SI computation. This is true in particular when efforts are not clearly associated to hand/wrist movements and when non-cyclical high-frequency activities are assessed.

\subsection{Main Findings}

Among the 30 studies included in the review (Table 1), IMUs were used only in five $[3,58,84,174,175]$, and dynamometers were used only in four $[58,182,194,205]$, while sEMG sensors are used in 27 studies $[3,57,58,65,66,87,156,162,164-167,173,175-179,182,183,186,188,201-205]$.

The results of these studies are mainly based on kinematic $[3,84,173,174,183,186,188]$, kinetic $[58,177,182,194,205]$ and sEMG $[3,57,58,65,66,87,156,162,164-167,173,175-179,182,183,186,188$, 201-205] data. Among the most investigated indices there are those sEMG-based. In particular, the most investigated indices are "muscle fatigue" (in nine studies [58,162,164-167,182,183,205]) and "muscle coactivation" (in seven studies [57,65,66,156,175-177]).

Instrumental evaluations were performed in 13 studies [3,58,84,87,156,173,174,177,178,186,188,203,204], muscle fatigue [58] by using kinematic data (i.e., joint angles [84] and range of motions [186,188], posture and more complex kinematic indices [3,175], trunk inclination [173]), kinetic data (i.e., compression and shear forces at the L5-S1 joint $[174,177]$ ) and sEMG data (i.e., time, amplitude and frequency parameters $[3,87,173,177,178,186,188,203,204]$, muscle fatigue [58] and coactivation [156,177]).

In these 13 studies, the most investigated working tasks are lifting tasks $[156,173,174,177,178]$ and manual handlings of low loads at high frequency $[58,186,188]$. As regards lifting tasks, all the results of these studies show that kinematic $[173,174]$ and sEMG-based $[156,173,177,178]$ indices significantly grow with the LI discriminating all the risk condition pairs. Moreover, when a correlation analysis has been performed, results show a good correlation between kinematic and sEMG-based indices and compression and shear forces [174,177]. Moreover, only one study [178] used machine-learning techniques and sEMG features. Results of these studies led to an improved biomechanical risk classification. As regard the studies regarding the manual handlings at low loads at high frequency, the results show that sEMG indices were sensitive to the risk classes $[58,186]$.

Many of these studies investigated specific work activities [3,84,87,186,188,204]: handling of low loads at high frequency on a redesigned checkout counter [189], laparoendoscopic single-site surgery [203], real-life operations of super-market cashiers [3], manual tasks in an industrial environment [84], sawmill work [87], manual handling on a supermarket greengrocery shelf [186], cleaning activities [204]. The results of these show that kinematic $[3,84,87,186,188]$ and sEMG $[3,87,186,188,204]$ data could be used in the risk assessment in work activities.

\section{Discussion}

In the attempt to reduce the risk of work-related musculoskeletal disorders several methods have been developed, accepted by the international literature and used in the workplace. In the last years, the most innovative wearable technologies and electronic smart devices, without interfering with the work activities performed by workers, have been introduced to improve the biomechanical risk assessment adapting it to all the work conditions and overcoming the limits of the current standardized methods. Indeed, these devices allow the estimation of biomechanical risk in real-time providing a direct feedback to the end-user who would be constantly monitored directly while at work.

In this review, we report on recent implementations of wearable sensors for quantitative instrumental-based biomechanical risk assessments in the prevention of WMSDs. Their use is desirable also in view of the concerns expressed within a recent article [206] regarding technical ISO standards on ergonomics and physical workloads. 
Table 1. Instrument-based techniques designed on current technological advances and performing direct measurements by using sensors attached to the workers

body. $\mathrm{M}$ and $\mathrm{F}$ indicate male and female respectively. IMUs: inertial measurement units; sEMG: surface electromyography.

\begin{tabular}{|c|c|c|c|c|c|c|c|}
\hline Wearable Sensors & Author (Year) & Sample & Work Activity & $\begin{array}{c}\text { Body Part } \\
\text { Assessment }\end{array}$ & Aim & Findings & Quantitative Data \\
\hline IMUs & $\begin{array}{l}\text { Vignais et al. } \\
\text { (2013) [84] }\end{array}$ & $12 \mathrm{M}$ & $\begin{array}{l}\text { Manual tasks in an } \\
\text { industrial environment }\end{array}$ & $\begin{array}{l}\text { Upper body } \\
\text { segment }\end{array}$ & $\begin{array}{l}\text { Risk assessment of musculoskeletal disorders in } \\
\text { real-time with two feedback }\end{array}$ & $\begin{array}{l}\text { A real-time feedback significantly decreased the outcome of } \\
\text { both globally as well as locally hazardous RULA values } \\
\text { associated with increased risk for musculoskeletal disorders }\end{array}$ & Joint angle \\
\hline IMUs & $\begin{array}{l}\text { Ranavolo et al. } \\
\text { (2017) [174] }\end{array}$ & $20 \mathrm{M}$ & Lifting task & All body & $\begin{array}{l}\text { Biomechanical risk assessment using kinematic } \\
\text { parameters }\end{array}$ & $\begin{array}{l}\text { Kinematic indices (Lifting Anergy Consumption) were } \\
\text { proved to be significantly growing with the LI, } \\
\text { discriminating all the risk condition pairs and well } \\
\text { correlating with forces that determine injuries at the } \\
\text { L5-S1 joint }\end{array}$ & $\begin{array}{l}\text { Joint angles, Center of } \\
\text { Mass, Mechanical } \\
\text { Energy }\end{array}$ \\
\hline IMUs and sEMG & $\begin{array}{l}\text { Peppoloni et al. } \\
\text { (2016) [3] }\end{array}$ & $8 \mathrm{M}, 3 \mathrm{~F}$ & $\begin{array}{l}\text { Real-life operations of } \\
\text { super-market cashiers }\end{array}$ & Upper limbs & $\begin{array}{l}\text { The system exploits IMU to reconstruct the } \\
\text { upper limb posture, modeled as a 7- degrees of } \\
\text { freedom kinematic chain. sEMG sensors are } \\
\text { used to assess forearm flexor muscles strain }\end{array}$ & $\begin{array}{l}\text { The system was capable of autonomously segmenting the } \\
\text { cycles and giving a score for each cycle }\end{array}$ & Joint angles, sEMG \\
\hline IMUs and sEMG & $\begin{array}{l}\text { Brandt et al. } \\
\text { (2018) [173] }\end{array}$ & $26 \mathrm{M}$ & Lifting task & Trunk & $\begin{array}{l}\text { To classify lifting activities into low and high } \\
\text { risk categories based on sEMG and trunk } \\
\text { inclination measurements }\end{array}$ & $\begin{array}{l}\text { Lifting tasks were characterized by a feature vector } \\
\text { composed of either the 90th, } 95 \text { th or 99th percentile of } \\
\text { sEMG activity level and trunk inclinations during the task } \\
\text { applying a linear discriminant analysis and a threshold } \\
\text { scheme to classify the lifting tasks with an accuracy of } \\
65.1-65.5 \%\end{array}$ & $\begin{array}{l}\text { Trunk inclination, } \\
\text { sEMG }\end{array}$ \\
\hline $\begin{array}{l}\text { Dynamometer and } \\
\text { sEMG }\end{array}$ & $\begin{array}{l}\text { Ranavolo et al. } \\
\text { (2017) [58] }\end{array}$ & $7 \mathrm{M}, 8 \mathrm{~F}$ & $\begin{array}{l}\text { Manual handling of low } \\
\text { loads at high frequency }\end{array}$ & Upper limbs & $\begin{array}{l}\text { To assess the muscle fatigue of the flexor } \\
\text { muscles before and after four levels of simulated } \\
\text { manual handling of low loads at high frequency; } \\
\text { to analyze the calculated fatigue indices to } \\
\text { understand whether they correctly classify the } \\
\text { risk; to correlate calculated fatigue indices to the } \\
\text { muscle behaviors during the execution of the } \\
\text { dynamic work task }\end{array}$ & $\begin{array}{l}\text { Fatigue index calculated from the brachioradialis was } \\
\text { sensitive to the interaction among risk classes, session } \\
\text { and gender }\end{array}$ & $\begin{array}{l}\text { Myoelectric } \\
\text { manifestation of } \\
\text { muscle fatigue }\end{array}$ \\
\hline $\begin{array}{l}\text { Hand-held } \\
\text { dynamometer }\end{array}$ & $\begin{array}{l}\text { Cadogan et al. } \\
\text { (2011) [194] }\end{array}$ & $23 \mathrm{M}, 17 \mathrm{~F}$ & $\begin{array}{l}\text { Active and passive } \\
\text { shoulder motion }\end{array}$ & Shoulder & $\begin{array}{l}\text { To establish the reliability of measures of } \\
\text { shoulder range of motion (ROM) and } \\
\text { muscle force }\end{array}$ & $\begin{array}{l}\text { Active ROM (flexion) demonstrated high levels of both } \\
\text { intra- and interexaminer reliability. Passive ROMs and } \\
\text { isometric force peaks shown acceptable levels of } \\
\text { intraexaminer reliability }\end{array}$ & $\begin{array}{l}\text { Range of motion and } \\
\text { muscle force }\end{array}$ \\
\hline $\begin{array}{l}\text { Grip } \\
\text { dynamometer and } \\
\text { sEMG }\end{array}$ & $\begin{array}{l}\text { Blackwell et al. } \\
\text { (1999) [205] }\end{array}$ & $18 \mathrm{M}$ & $\begin{array}{l}\text { Isometric and } \\
\text { submaximal gripping } \\
\text { contractions }\end{array}$ & $\begin{array}{l}\text { Flexor digitorum } \\
\text { superficialis } \\
\text { muscle }\end{array}$ & $\begin{array}{l}\text { To investigate the effect of grip span on } \\
\text { isometric grip force and fatigue of the flexor } \\
\text { digitorum superficialis muscle during sustained } \\
\text { voluntary contractions }\end{array}$ & $\begin{array}{l}\text { Fatigue of flexor digitorum superficialis did not change as a } \\
\text { function of grip size. Middle grip sizes allowed for greater } \\
\text { absolute forces than the small or large size. When } \\
\text { contractions are at } 60-65 \% \text { MVC and the muscle is allowed } \\
\text { to fatigue, grip size may be less infuential than when } \\
\text { maximal absolute force is required }\end{array}$ & $\begin{array}{l}\text { Myoelectric } \\
\text { manifestation of } \\
\text { muscle fatigue }\end{array}$ \\
\hline $\begin{array}{l}\text { Dynamometer and } \\
\text { sEMG }\end{array}$ & $\begin{array}{l}\text { Roman-Liu et } \\
\text { al. (2004) [182] }\end{array}$ & $10 \mathrm{M}$ & $\begin{array}{l}\text { Exerting maximal force } \\
\text { and tests under specific } \\
\text { load conditions }\end{array}$ & $\begin{array}{l}\text { Arm and hand } \\
\text { muscles }\end{array}$ & $\begin{array}{l}\text { To discriminate fatigue of upper limb muscles } \\
\text { depending on the external load, through the } \\
\text { development and analysis of a muscle } \\
\text { fatigue index }\end{array}$ & $\begin{array}{l}\text { External loads induced modifications in the fatigue of the } \\
\text { biceps brachii caput breve, extensor carpi radialis brevis, } \\
\text { and flexor carpi ulnaris muscles }\end{array}$ & $\begin{array}{l}\text { Myoelectric } \\
\text { manifestation of } \\
\text { muscle fatigue }\end{array}$ \\
\hline $\begin{array}{l}\text { sEMG and } \\
\text { electrogoniometers }\end{array}$ & $\begin{array}{l}\text { Granata and } \\
\text { Marras (2000) } \\
\text { [57] }\end{array}$ & $10 \mathrm{M}$ & Lifting task & $\begin{array}{l}\text { Trunk extensors } \\
\text { and flexors } \\
\text { muscles }\end{array}$ & $\begin{array}{l}\text { To evaluate whether increased biomechanical } \\
\text { stability associated with antagonistic } \\
\text { co-contraction was capable of stabilizing the } \\
\text { related increase in spinal load }\end{array}$ & $\begin{array}{l}\text { Coactivation was associated with a } 12 \% \text { to } 18 \% \text { increase in } \\
\text { spinal compression and a } 34 \% \text { to } 64 \% \text { increase in stability. } \\
\text { Spinal load and stability increased with trunk flexion }\end{array}$ & $\begin{array}{l}\text { Muscle coactivation, } \\
\text { spinal load and } \\
\text { stability }\end{array}$ \\
\hline
\end{tabular}


Table 1. Cont

\begin{tabular}{|c|c|c|c|c|c|c|c|}
\hline Wearable Sensors & Author (Year) & Sample & Work Activity & $\begin{array}{c}\text { Body Part } \\
\text { Assessment }\end{array}$ & Aim & Findings & Quantitative Data \\
\hline sEMG & $\begin{array}{l}\text { Sundelin (1993) } \\
{[166]}\end{array}$ & $12 \mathrm{~F}$ & $\begin{array}{l}\text { Repetitive arm work } \\
\text { continuously without } \\
\text { pauses and with pauses }\end{array}$ & $\begin{array}{l}\text { Trapezius and } \\
\text { infraspinatus } \\
\text { muscles }\end{array}$ & $\begin{array}{l}\text { Fatigue assessment in shoulder and neck } \\
\text { muscles during continuous work and } \\
\text { during work with organized } \\
\text { pause activities }\end{array}$ & $\begin{array}{l}\text { Muscle fatigue with a decrease in the mean power frequency and } \\
\text { an increase in root mean square amplitudes was found both } \\
\text { during continuous work and work with pause activities. } \\
\text { The muscle fatigue was less pronounced when pause activities } \\
\text { were introduced into the work. Fatigue patterns were lower } \\
\text { during the second hour, indicating adaptation to the work task } \\
\text { and work pace. The ratings of perceived exertion and discomfort } \\
\text { were similar during work with and without pauses and were } \\
\text { higher during the second hour of work }\end{array}$ & $\begin{array}{l}\text { Myoelectric } \\
\text { manifestation of } \\
\text { muscle fatigue }\end{array}$ \\
\hline sEMG & $\begin{array}{l}\text { Sundelin and } \\
\text { Hagberg (1992) } \\
\text { [165] }\end{array}$ & $6 \mathrm{~F}$ & $\begin{array}{l}\text { Repetitive arm work for } \\
1 \mathrm{~h}\end{array}$ & $\begin{array}{l}\text { Trapezius and } \\
\text { infraspinatus } \\
\text { muscles }\end{array}$ & $\begin{array}{l}\text { Fatigue assessment in shoulder and neck } \\
\text { muscles during work paced by the } \\
\text { methods-time measurement system }\end{array}$ & $\begin{array}{l}\text { Muscle fatigue with a decrease in the mean power frequency and } \\
\text { an increase in root mean square amplitudes was found }\end{array}$ & $\begin{array}{l}\text { Myoelectric } \\
\text { manifestation of } \\
\text { muscle fatigue }\end{array}$ \\
\hline sEMG & $\begin{array}{l}\text { Hansson et al. } \\
\text { (1992) [167] }\end{array}$ & $33 \mathrm{~F}$ & Static endurance test & $\begin{array}{l}\text { Trapezius and } \\
\text { deltoid muscles }\end{array}$ & $\begin{array}{l}\text { Muscular fatigue assessment during a } \\
\text { standardized isometric endurance test in } \\
\text { women with a static workload, with and } \\
\text { without neck/shoulder disorders }\end{array}$ & $\begin{array}{l}\text { The endurance time for a group of women in industrial work } \\
\text { with repetitive short cycled work tasks who were diagnosed with } \\
\text { neck/shoulder disorders was significantly shorter than for a } \\
\text { group with the same work, but without neck/shoulder disorders } \\
\text { and shorter than for a control group. There were no significant } \\
\text { differences in muscle fatigue between the three groups } \\
\text { considered }\end{array}$ & $\begin{array}{l}\text { Myoelectric } \\
\text { manifestation of } \\
\text { muscle fatigue }\end{array}$ \\
\hline sEMG & $\begin{array}{l}\text { Mathiassen } \\
\text { and Winkel } \\
(1996)[164]\end{array}$ & $8 \mathrm{~F}$ & $\begin{array}{l}\text { Assembly task with } \\
\text { different combinations } \\
\text { of work pace (120 or } 100 \\
\text { according to the } \\
\text { methods-time } \\
\text { measurement system, } \\
\text { MTM), break allowance } \\
\text { and duration of the } \\
\text { working day }\end{array}$ & Trapezius muscle & $\begin{array}{l}\text { Fatigue assessment in shoulder and neck } \\
\text { muscles in different industrial } \\
\text { assembly task }\end{array}$ & $\begin{array}{l}\text { During } 6 \mathrm{~h} \text { of work at } 120 \mathrm{MTM} \text { the EMG amplitude from the } \\
\text { upper trapezius muscle increased by about } 11 \% \text {, the EMG zero } \\
\text { crossing rate decreased by about } 2.5 \% \text {, and perceived fatigue } \\
\text { increased. When work pace was reduced to } 100 \text { MTM, the upper } \\
\text { trapezius EMG amplitude decreased by } 20 \% \text { and became less } \\
\text { variable, perceived fatigue decreased and shoulder tenderness } \\
\text { was reduced by about } 5 \% \text {. Added breaks, whether active or } \\
\text { passive, had no apparent effects on upper trapezius load during } \\
\text { work or on physiological responses }\end{array}$ & $\begin{array}{l}\text { Myoelectric } \\
\text { manifestation of } \\
\text { muscle fatigue }\end{array}$ \\
\hline sEMG & $\begin{array}{l}\text { Cabeças (2007) } \\
{[204]}\end{array}$ & $1 \mathrm{M}, 19 \mathrm{~F}$ & Cleaning activities & $\begin{array}{l}\text { Wrist flexor and } \\
\text { extensor muscles }\end{array}$ & $\begin{array}{l}\text { A modified application of the Strain Index } \\
\text { method, in evaluation of effort-related } \\
\text { variables in cleaning activities }\end{array}$ & $\begin{array}{l}\text { EMG data were found to be a useful alternative to observational } \\
\text { methods. The most critical cleaning activities and that with } \\
\text { comparatively lower risk to distal upper extremity disorders } \\
\text { were individuated }\end{array}$ & $\begin{array}{l}\text { SEMG data (time, } \\
\text { intensity, frequency } \\
\text { of efforts) }\end{array}$ \\
\hline sEMG & $\begin{array}{l}\text { Bosch et al. } \\
\text { (2009) [183] }\end{array}$ & $5 \mathrm{M}, 5 \mathrm{M}$ & $\begin{array}{l}\text { Assembly task } \\
\text { (construction and break } \\
\text { down a tower) }\end{array}$ & Trapezius muscle & $\begin{array}{l}\text { To determine whether muscle fatigue } \\
\text { develop in the upper trapezius muscle in } \\
\text { two assembly tasks involving contractions } \\
\text { of different low-intensity levels and } \\
\text { whether these indications of fatigue are } \\
\text { homogeneously distributed across } \\
\text { different muscle parts }\end{array}$ & $\begin{array}{l}\text { Recordings during task and test showed a significant decrease in } \\
\text { the mean power frequency, at both intensity levels while the } \\
\text { amplitude remained constant. Significantly different temporal } \\
\text { patterns were found for the mean power frequency decrease. No } \\
\text { differences in manifestations of muscle fatigue development } \\
\text { were found between different parts of the muscle }\end{array}$ & $\begin{array}{l}\text { Myoelectric } \\
\text { manifestation of } \\
\text { muscle fatigue }\end{array}$ \\
\hline sEMG & $\begin{array}{l}\text { de Looze et al. } \\
\text { (2009) [162] }\end{array}$ & - & $\begin{array}{l}\text { Repetitive } \\
\text { low-level force activities }\end{array}$ & Shoulder muscles & $\begin{array}{l}\text { Review of studies on objectively } \\
\text { measurable fatigue related changes in time } \\
\text { in low-level force activities }\end{array}$ & $\begin{array}{l}\text { Electromyographic manifestations of fatigue in the trapezius } \\
\text { muscle appear in low-force activities like light manual work and } \\
\text { assembly when the intensity level is about } 15-20 \% \text { MVC. } \\
\text { The amplitude increases ranged from } 3 \% \text { to } 27 \% \text {, while the mean } \\
\text { power frequency decreases range from } 0.9 \% \text { to } 11 \% \text {. } \\
\text { Furthermore, local muscle fatigue seems to occur in some light } \\
\text { manual activities and could be considered a risk indicator }\end{array}$ & $\begin{array}{l}\text { Myoelectric } \\
\text { manifestation of } \\
\text { muscle fatigue }\end{array}$ \\
\hline
\end{tabular}


Table 1. Cont

\begin{tabular}{|c|c|c|c|c|c|c|c|}
\hline Wearable Sensors & Author (Year) & Sample & Work Activity & $\begin{array}{l}\text { Body Part } \\
\text { Assessment }\end{array}$ & Aim & Findings & Quantitative Data \\
\hline sEMG & $\begin{array}{l}\text { Jones and } \\
\text { Kumar (2010) } \\
{[87]}\end{array}$ & 89 & $\begin{array}{l}\text { Sawmill work } \\
\text { (Board-edger operator; } \\
\text { Lumber grader; Saw } \\
\text { filer; Trim-saw operator) }\end{array}$ & $\begin{array}{l}\text { Wrist flexor and } \\
\text { extensor muscles }\end{array}$ & $\begin{array}{l}\text { To examine the agreement between } 5 \\
\text { ergonomic risk assessment methods } \\
\text { calculated on the basis of quantitative } \\
\text { exposure measures and to examine the } \\
\text { ability of the methods to correctly classify } \\
\text { risk job }\end{array}$ & $\begin{array}{l}\text { RULA and SI were best (correct classification rates of } 99 \text { and } 97 \% \\
\text { respectively). The quantitative ACGIH-TLV for monotask hand } \\
\text { work and Borg scale were worst (misclassification rates of } 86 \text { and } \\
28 \% \text { respectively) }\end{array}$ & $\begin{array}{l}\mathrm{SEMG} \text { and } \\
\text { electrogoniometric data }\end{array}$ \\
\hline sEMG & $\begin{array}{l}\text { Nimbarte et al. } \\
\text { (2010) [201] }\end{array}$ & $10 \mathrm{M}, 5 \mathrm{~F}$ & $\begin{array}{l}\text { Lifting tasks carried out } \\
\text { at shoulder height in } \\
\text { extended, neutral, and } \\
\text { flexed neck postures }\end{array}$ & $\begin{array}{l}\text { Neck muscle } \\
\text { (sternocleidomastoid } \\
\text { and the upper } \\
\text { trapezius) }\end{array}$ & $\begin{array}{l}\text { To evaluate physical risk factors (force and } \\
\text { posture) associated with neck disorders } \\
\text { among construction workers }\end{array}$ & $\begin{array}{l}\text { Increase in the weight lifted increased the activation of the neck } \\
\text { muscles. The sternocleidomastoid muscle was most active at the } \\
\text { extended neck posture, while the upper trapezius muscle was } \\
\text { most active at the flexed neck posture }\end{array}$ & sEMG data \\
\hline sEMG & $\begin{array}{l}\text { Jia et al. (2011) } \\
\text { [202] }\end{array}$ & $19 \mathrm{M}, 5 \mathrm{~F}$ & $\begin{array}{l}\text { Carrying, erecting, } \\
\text { lifting and moving tasks }\end{array}$ & Trunk muscles & $\begin{array}{l}\text { Using a model, to predict trunk } \\
\text { muscle forces and low back loads during a } \\
\text { wide range of panel erection tasks }\end{array}$ & $\begin{array}{l}\text { Reasonable levels of correspondence were found between } \\
\text { measured and predicted lumbosacral moments, though } \\
\text { predictive ability varied between tasks and rotation planes }\end{array}$ & $\begin{array}{l}\text { Trunk muscle forces } \\
\text { and low back loads }\end{array}$ \\
\hline sEMG & $\begin{array}{l}\text { Draicchio et al. } \\
\text { (2012) [188] }\end{array}$ & $10 \mathrm{~F}$ & $\begin{array}{l}\text { Work activities of } \\
\text { supermarket cashiers }\end{array}$ & $\begin{array}{l}\text { Shoulder and } \\
\text { trunk muscles }\end{array}$ & $\begin{array}{l}\text { To provide a biomechanical evaluation of } \\
\text { cashiers working at a checkout counter } \\
\text { before and after a redesign, on the basis of } \\
\text { changes induced in time, kinematic and } \\
\text { electromyographic variables }\end{array}$ & $\begin{array}{l}\text { The ergonomics intervention (disk wheel) represented a valid aid } \\
\text { for reducing biomechanical overload in cashiers and the standing } \\
\text { position resulted biomechanically more advantageous. The range } \\
\text { of motion values of upper limb and trunk were lowest after the } \\
\text { intervention and in the standing position }\end{array}$ & $\begin{array}{l}\text { Range of motion and } \\
\text { sEMG data }\end{array}$ \\
\hline sEMG & $\begin{array}{l}\text { Perez-Duarte } \\
\text { et al. (2014) } \\
\text { [203] }\end{array}$ & $10 \mathrm{M}, 4 \mathrm{~F}$ & $\begin{array}{l}\text { Conventional } \\
\text { laparoscopic and } \\
\text { laparoendoscopic } \\
\text { single-site surgery }\end{array}$ & Upper body & $\begin{array}{l}\text { To determine inherent risk levels for wrist } \\
\text { disorders assessing the degree of arm and } \\
\text { back muscleactivity as well as spatial } \\
\text { configuration of hand and wrist }\end{array}$ & $\begin{array}{l}\text { Muscular activity for trapezius and forearm extensor muscles } \\
\text { was significantly lower in conventional laparoscopy compared } \\
\text { with single-site approach. A better wrist position was found } \\
\text { during laparoendoscopic single-site surgery compared with } \\
\text { traditional laparoscopy }\end{array}$ & sEMG data \\
\hline sEMG & $\begin{array}{l}\text { Ranavolo et al. } \\
\text { (2015) [156] }\end{array}$ & $10 \mathrm{M}$ & Lifting task & $\begin{array}{l}\text { Trunk extensors } \\
\text { and flexors } \\
\text { muscles }\end{array}$ & $\begin{array}{l}\text { A method developing for the monitoring } \\
\text { of the co-activation of more than two } \\
\text { muscles during lifting task }\end{array}$ & Heavier lifting conditions resulted in higher co-activation values & Muscle coactivation \\
\hline sEMG & $\begin{array}{l}\text { Silvetti et al. } \\
\text { (2015) [186] }\end{array}$ & $5 \mathrm{M}$ & $\begin{array}{l}\text { Manual handling on a } \\
\text { supermarket } \\
\text { greengrocery Shelf }\end{array}$ & $\begin{array}{l}\text { Sholuder and } \\
\text { trunk muscles }\end{array}$ & $\begin{array}{l}\text { To investigate the effect of different shelf } \\
\text { levels and load weights on the workers' } \\
\text { biomechanical load }\end{array}$ & $\begin{array}{l}\text { Shelf level had a significant effect on most of the parameters } \\
\text { examined. Weight did not affect the biomechanical load }\end{array}$ & $\begin{array}{l}\text { Ankle joint range of } \\
\text { motion and } \\
\text { sEMG data }\end{array}$ \\
\hline sEMG & $\begin{array}{l}\text { Shair et al. } \\
\text { (2017) [179] }\end{array}$ & - & Manual lifting & $\begin{array}{l}\text { Arm and trunk } \\
\text { muscles }\end{array}$ & $\begin{array}{l}\text { To review the impact of EMG processing in } \\
\text { fatigue assessment during manual lifting } \\
\text { and to determine the best possible } \\
\text { techniques for lifting applications }\end{array}$ & $\begin{array}{l}\text { Bilinear Time-Frequency Distribution (TFD) could perform better } \\
\text { than the linear TFD such as Short-Time Fourier Transform (STFT), } \\
\text { spectrogram, and Wavelet Transform (WT). Bilinear TFD suffered } \\
\text { the cross term effects, that could be removed }\end{array}$ & sEMG data \\
\hline sEMG & $\begin{array}{l}\text { Le et al. (2017) } \\
\text { [65] }\end{array}$ & - & $\begin{array}{l}\text { Isometric loading, } \\
\text { Lifting, Isometric } \\
\text { quasi-static exertions, } \\
\text { motions at different } \\
\text { speeds }\end{array}$ & All body & $\begin{array}{l}\text { Understanding of the factors that may } \\
\text { influence coactivation and define the } \\
\text { necessary variables for a coactivation index } \\
\text { that can be used for a variety of tasks }\end{array}$ & $\begin{array}{l}\text { The index appeared to be sensitive to conditions where higher } \\
\text { coactivation would be expected. These conditions of higher } \\
\text { coactivation included tasks involving higher degrees of control. } \\
\text { Precision placement tasks required about } 20 \% \text { more coactivation } \\
\text { than tasks not requiring precision, lifting at chest height required } \\
\text { approximately twice the coactivation as mid-thigh height, and } \\
\text { pushing fast speeds with turning also required at least twice the } \\
\text { level of coactivity as slow or preferred speeds }\end{array}$ & Muscle coactivation \\
\hline sEMG & $\begin{array}{l}\text { Le et al. (2017) } \\
\text { [66] }\end{array}$ & $7 \mathrm{M}, 10 \mathrm{~F}$ & $\begin{array}{l}\text { Lifting/lowerin, } \\
\text { pushing, and Valsalva } \\
\text { maneuvers }\end{array}$ & $\begin{array}{l}\text { Trunk extensors } \\
\text { and flexors } \\
\text { muscles }\end{array}$ & $\begin{array}{l}\text { To describe the development of an index to } \\
\text { assess coactivity for the lumbar spine and } \\
\text { test its ability to differentiate between } \\
\text { various complex dynamic tasks }\end{array}$ & $\begin{array}{l}\text { Coactivity for dynamic tasks necessitates the understanding of } \\
\text { local maxima and minima, different phases of loading, its effect } \\
\text { on peak spinal loads, and cumulative responses. It was } \\
\text { postulated that a mind-body interaction exists which warrants a } \\
\text { continuously defined agonist/antagonist coactivation index } \\
\text { sensitive enough to detect those differences }\end{array}$ & Muscle coactivation \\
\hline
\end{tabular}


Table 1. Cont

\begin{tabular}{|c|c|c|c|c|c|c|c|}
\hline Wearable Sensors & Author (Year) & Sample & Work Activity & $\begin{array}{c}\text { Body Part } \\
\text { Assessment }\end{array}$ & Aim & Findings & Quantitative Data \\
\hline sEMG & $\begin{array}{l}\text { Le et al. (2018) } \\
\text { [175] }\end{array}$ & $5 \mathrm{M}, 7 \mathrm{~F}$ & $\begin{array}{l}\text { Different combinations } \\
\text { of head posture and } \\
\text { speed of movement }\end{array}$ & Neck muscles & $\begin{array}{l}\text { Develop a coactivation index for the neck } \\
\text { and test its effectiveness with complex } \\
\text { dynamic head motions }\end{array}$ & $\begin{array}{l}\text { Complex motions involving twisting and higher speed had } \\
\text { higher magnitudes of coactivation than uniplanar motions in the } \\
\text { sagittal or lateral plane, which was expected. The coupled } \\
\text { motion of flexion and twisting showed four to five times higher } \\
\text { coactivation than uniplanar movements }\end{array}$ & Muscle coactivation \\
\hline sEMG & $\begin{array}{l}\text { Ranavolo et al. } \\
\text { (2018) [177] }\end{array}$ & $16 \mathrm{M}$ & Lifting task & $\begin{array}{l}\text { Trunk extensors } \\
\text { and flexors } \\
\text { muscles }\end{array}$ & $\begin{array}{l}\text { SEMG activities of the trunk muscles } \\
\text { and forces at the L5-S1 joint to identify } \\
\text { sEMG-based indices related to the risk } \\
\text { level and to the forces at the L5-S1 joint }\end{array}$ & $\begin{array}{l}\text { sEMG indices were proved to be significantly growing with the } \\
\text { LI, discriminating all the risk condition pairs and well correlating } \\
\text { with compression and shear forces that determine injuries at the } \\
\text { L5-S1 joint }\end{array}$ & $\begin{array}{l}\text { sEMG data, muscle } \\
\text { coactivation } \\
\text { and forces at the } \\
\text { L5-S1 joint }\end{array}$ \\
\hline sEMG & $\begin{array}{l}\text { Le et al. (2018) } \\
\text { [176] }\end{array}$ & $7 \mathrm{M}, 10 \mathrm{~F}$ & $\begin{array}{l}\text { Lifting/lowering, } \\
\text { pushing and Valsalva } \\
\text { manoeuvres }\end{array}$ & Trunk muscles & $\begin{array}{l}\text { To provide an approach to assess } \\
\text { multi-muscle coactivation comparing } \\
\text { this index to a coactivation index defined } \\
\text { by a biologically assisted lumbar spine } \\
\text { model to differentiate between tasks }\end{array}$ & $\begin{array}{l}\text { The EMG-based index was comparable to the index defined by a } \\
\text { biologically assisted model. The EMG-based index provided a } \\
\text { universal, usable method to assess the neuromuscular effort } \\
\text { associated with coactivation for complex dynamic tasks }\end{array}$ & Muscle coactivation \\
\hline sEMG & $\begin{array}{l}\text { Varrecchia et al. } \\
\text { (2018) [178] }\end{array}$ & $10 \mathrm{M}$ & Lifting task & $\begin{array}{l}\text { Trunk extensors } \\
\text { and flexors } \\
\text { muscles }\end{array}$ & $\begin{array}{l}\text { Biomechanical risk assessment using } \\
\text { sEMG and neural network }\end{array}$ & $\begin{array}{l}\text { Approaches based on machine-learning techniques and sEMG } \\
\text { feature led to an improved biomechanical risk classification }\end{array}$ & $\begin{array}{l}\text { sEMG data in time } \\
\text { and frequency domain }\end{array}$ \\
\hline
\end{tabular}


In this "discussion paper" the authors underlined, among the others, how: (i) the production of these standards differed substantially from evidence-based practical guidelines; (ii) it is not clear why the ISO subcommittee preferred one method of risk assessment over others; (iii) some statements in ISO 11228 series appear to be based on personal opinions and in contrast with scientific evidence from the literature; (iv) ISO standards are an effort by a self-identified committee of interested people to agree on "how something should be made" in order to facilitate exchange of goods, services, or other similar endeavors; (v) ISO standards should be used with caution. For these reasons instrumental-based tool will play an increasingly important role in both direct evaluations and in the rating of standard methods, also in consideration that several factors implying work-related musculoskeletal disorders interact at the same time. Therefore, it will be crucial to monitor all of them by using more than one method at the same time ensuring a more thorough evaluation of risk factors. On the other hand, a lot of attention must be paid because the use of more than one method can rapidly lead to unacceptably high costs for the practitioner, both from a time and money viewpoint $[207,208]$.

In this context, the technologies accredited to be used are without doubt inertial measurement units (IMUs), instrumented gloves and surface electromyography (sEMG) sensors, although other new tools are appearing in research laboratories and the workplace. Among these, smart footwear-based wearable systems [209] will surely be useful because they will permit, by recording ground reaction forces through integrated tri-axial force sensors, an inverse dynamics analysis [210-212]. For their simplicity, vision-based tracking systems are also potentially useful for the rating of standardized methods as proposed for assessing the movements of workers within quick exposure check tools [83]. Wearable miniaturized sensors can monitor workers' motor behavior if individually placed on the body segments or embedded in elastic suits. The latter use is also the most probable because the research activity is working fast on the development of artificial muscles, materials able to reversibly contract, expand, and rotate due to an external stimulus $[198,213,214]$. These devices, that can be enriched by several material characteristics, textile layers, elastic components, diagonal and lateral seams and pneumatic mechanisms [215] are envisioned as actuators for silent, soft and compliant assistive devices [216] acting as force multiplier systems by helping workers to reduce their effort. These suits/devices can also embed miniaturized sensors which will also serve for their control through, for instance, effective feedforward anticipation mechanisms. Furthermore, numerous devices have been developed to support the trunk during dynamic lifting tasks. sEMG will allow the detection of the early preparatory muscle activities to classify muscle loading and to initiate appropriate device activation. It has been shown that preparatory muscle activity can be leveraged to identify the intent to lift a weight up to $100 \mathrm{~ms}$ prior to load-onset [217]. The reduction of the effort will also be guaranteed by highly adaptive production processes.

Although the use of new innovative technologies for biomechanical risk assessment is only at the beginning (see Table 1), the literature shows that these instrumental approaches could be used to classify lifting tasks into low and high risk categories. The reported studies used wearable sensors, such as inertial measurement units, dynamometers and surface electromyography sensors, for biomechanical risk assessment in different work activities: lifting tasks $[58,65,66,173,176,177,201]$ manual tasks in an industrial environment $[84,164,183]$, manual handling $[174,186]$, work in supermarket $[3,188]$, repetitive work [165,166], cleaning activities [204], surgery work [203].

The results of these studies show that the indices used for the instrumented-based approaches are proved to correlate with the variables that determine the injuries. Particularly, two of the most promising indices/approaches proposed in literature for a work activity such as manual lifting, are the multi-muscle coactivation index $[65,66,156,177]$ and machine-learning techniques based on sEMG features [178] while for this work activity, the literature shows that the fatigue indices need further elaboration [179]. Probably the most critical factor in lifting activities is the frequency of the lifting action which at the current status cannot be determined by instrumental methods [177]. It is necessary to be able to parameterize the risk levels associated to it. On the other hand, frequency of the actions is taken into consideration in work activities concerning the repetitive movement when the assessment 
is performed by using fatigue estimation before and after the work activity [58]. In some studies, wearable technologies are used for the rating of the standard methods (see Section 3.4). In these studies, the observed discrepancies between the evaluators can be due to several factors related to both the human and the procedural sides [203]: artifacts in the sEMG signals, difficulties in performing his real maximal voluntary contraction for the muscles considered, and underestimation by the human investigators of the actual efforts exerted by the workers.

From a technological point of view IMUs do not suffer from such limitations but if a high number of units is required for whole-body bio-mechanical studies in ergonomics, a high data transfer time could be required with both the Wi-Fi and Bluetooth protocols. Furthermore, IMUs fail to precisely measure translational motion and suffer from drift. Finally, IMUs can fail in the presence of magnetic fields in the workplace if they have embedded magnetic sensors. As regards limitations associated to sEMG, crosstalk muscle signals, electrode-skin impedance, noise and problems related to the electrode location, size, configuration and distance are the main critical factors [218]. To optimize the sEMG measures it is essential to use reference books such as the "Atlas of Muscle Innervation Zones" [219]. For both IMUs and sEMG sensors the energy consumption and the consequent battery discharge do not seem to be problems anymore, thanks to the long life of the most recent batteries. Two main limitations are ascribable to dynamometers: forces are commonly measured in only one direction and the form factor of the handles is not characteristic of most handles encountered during everyday work activities [220-222].

Finally, the heterogeneity in experimental procedures of the articles included in this review such as in working tasks, body segments, muscles and instrumental-based indices, has not allowed a valid complex statistical analysis combining the results as in other systematic reviews. For this reason, we have avoided a statistical pooling and summarized the data narratively [222-225]. The lack of a meta-analysis can be considered a limitation of the study.

\section{Conclusions}

The analysis of the papers reported in this review sheds light on the fact that still too few researchers foresee the use of wearable technologies for biomechanical risk assessment although the requirement to obtain increasingly quantitative evaluations, the recent miniaturization process and the need to follow a constantly evolving manual handling scenario is prompting their use. Therefore, the use of new innovative technologies for biomechanical risk assessment is only at its initial stage, but the authors of this review believe that this process is unstoppable, as it is happening in all the other areas of medicine and beyond. Obviously, it will be necessary for any validation to follow evidence-based medicine/policy/legislation multistep scientific approaches by designing rigorous laboratory and epidemiologic studies, by replicating them by independent research groups and by systematically evaluating them through transparent review processes. We are however convinced that, even if such use should fail in ergonomic practice, the huge knowledge that will derive from its experimentation will allow the optimization of the current standardized methods or the developments of the new ones.

Author Contributions: R.A. performed electronic searches. R.A., T.V. and A.S. assessed titles and abstracts of the articles. R.A., F.D., T.V., A.S. and S.I. resolved disagreements among reviewers by scheduling dedicated consensus meetings. R.A., F.D., T.V., A.S. and S.I. wrote the text and did work revision.

Funding: This research received no external funding.

Conflicts of Interest: The authors declare no conflict of interest. 


\section{Abbreviations}

\begin{tabular}{|c|c|}
\hline WMSDs & work-related musculoskeletal disorders \\
\hline HRC & human-robot collaboration \\
\hline WLBDs & work-related low-back disorders \\
\hline UL-WMSDs & upper limb work-related musculoskeletal disorders \\
\hline RNLE & revised NIOSH lifting equation \\
\hline KIM-MHO & key indicator method \\
\hline BIPP & back injury prevention project \\
\hline PTAI & patient transfer assessing instrument \\
\hline RAPP & risk assessment of pushing and pulling tool \\
\hline HAL & hand activity level \\
\hline SI & strain index \\
\hline OCRA & occupational repetitive actions \\
\hline QEC & quick exposure check \\
\hline OREGE & outil de repérage et d'evaluation des gestes \\
\hline PATH & posture, activity, tools and handling \\
\hline RULA & rapid upper limb assessment method \\
\hline REBA & rapid entire body assessment method \\
\hline ACGIH TLV & $\begin{array}{l}\text { American conference of governmental industrial hygienist's threshold limit value } \\
\text { for mono-task hand work }\end{array}$ \\
\hline ART & assessment of repetitive task \\
\hline ULRA & upper limb risk assessment \\
\hline MAC & manual handling assessment chart \\
\hline ALLA & agricultural lower limb assessment \\
\hline IMUs & inertial measurement units \\
\hline sEMG & surface electromyography \\
\hline ARVs & average rectified values \\
\hline RMS & root mean square \\
\hline LI & lifting index \\
\hline LEC & lifting energy consumption \\
\hline TMCi & time-varying multi-muscle co-activation index \\
\hline $\mathrm{ROM}$ & range of motion \\
\hline MVC & maximal voluntary contraction \\
\hline
\end{tabular}

\section{References}

1. Eliasson, K.; Palm, P.; Nyman, T.; Forsman, M. Inter- and Intra- Observer Reliability of Risk Assessment of Repetitive Work without an Explicit Method. Appl. Ergon. 2017, 62, 1-8. [CrossRef] [PubMed]

2. Valero, E.; Sivanathan, A.; Bosché, F.; Abdel-Wahab, M. Musculoskeletal disorders in construction: A review and a novel system for activity tracking with body area network. Appl. Ergon. 2016, 54, 120-130. [CrossRef] [PubMed]

3. Peppoloni, L.; Filippeschi, A.; Ruffaldi, E.; Avizzano, C.A. (WMSDs issue) A novel wearable system for the online assessment of risk for biomechanical load in repetitive efforts. Int. J. Ind. Ergon. 2016, 52, 1-11. [CrossRef]

4. Takala, E.P.; Pehkonen, I.; Forsman, M.; Hansson, G.A.; Mathiassen, S.E.; Neumann, W.P.; Sjøgaard, G.; Veiersted, K.B.; Westgaard, R.H.; Winkel, J. Systematic Evaluation of Observational Methods Assessing Biomechanical Exposures at Work. Scand. J. Work. Environ. Health 2010, 36, 3-24. [CrossRef] [PubMed]

5. Vieweg, H. An Introduction to Mechanical Engineering: Study on the Competitiveness of the EU Mechanical Engineering Industry; Within the Framework Contract of Sectoral Competitiveness Studies [Electronic Resource]; European Commission: Brussels, Belgium, 2012.

6. ISO 8373. Robots and Robotic Devices_Vocabulary; ISO: Geneva, Switzerland, 2012. 
7. Saito, T.; Hoshi, T.; Ikeda, H.; Okabe, K. Global harmonization of safety regulations for the use of industrial robots-permission of collaborative operation and a related study by JNIOSH. Ind. Health 2015, 53, 498-504. [CrossRef] [PubMed]

8. Huysamen, K.; de Looze, M.; Bosch, T.; Ortiz, J.; Toxiri, S.; O'Sullivan, L.W. Assessment of an active industrial exoskeleton to aid dynamic lifting and lowering manualhandling tasks. Appl. Ergon. 2018, 68, 125-131. [CrossRef] [PubMed]

9. Weston, E.B.; Alizadeh, M.; Knapik, G.G.; Wang, X.; Marras, W.S. Biomechanical evaluation of exoskeleton use on loading of the lumbar spine. Appl. Ergon. 2018, 68, 101-108. [CrossRef] [PubMed]

10. de Looze, M.P.; Bosch, T.; Krause, F.; Stadler, K.S.; O’Sullivan, L.W. Exoskeletons for industrial application and their potential effects on physical work load. Ergonomics 2016, 59, 671-681. [CrossRef] [PubMed]

11. Bosch, T.; van Eck, J.; Knitel, K.; de Looze, M. The effects of a passive exoskeleton on muscle activity, discomfort and endurance time in forward bending work. Appl. Ergon. 2016, 54, 212-217. [CrossRef] [PubMed]

12. Sylla, N.; Bonnet, V.; Colledani, F.; Fraisse, P. Ergonomic contribution of ABLE exoskeleton in automotive industry. Int. J. Ind. Ergon. 2014, 44, 475-481. [CrossRef]

13. Camomilla, V.; Bergamini, E.; Fantozzi, S.; Vannozzi, G. Trends Supporting the In-Field Use of Wearable Inertial Sensors for Sport Performance Evaluation: A Systematic Review. Sensors (Basel) 2018, 18, 873. [CrossRef] [PubMed]

14. Chambers, R.; Gabbett, T.J.; Cole, M.H.; Beard, A. The use of wearable microsensors to quantify sport-specific movements. Sports Med. 2015, 45, 1065-1081. [CrossRef] [PubMed]

15. Parkka, J.; Ermes, M.; Korpipaa, P.; Mantyjarvi, J.; Peltola, J.; Korhonen, I. Activity classification using realistic data from wearable sensors. IEEE Trans. Inf. Technol. Biomed. 2006, 10, 119-128. [CrossRef] [PubMed]

16. Namal, S.; Senanayake, A.; Chong, V.; Chong, J.; Sirisinghe, G. Analysis of soccer actions using wireless accelerometers. In Proceedings of the 2006 IEEE International Conference on Industrial Informatics, Singapore, 16-18 August 2006; pp. 664-669.

17. Johansson, D.; Malmgren, K.; Alt Murphy, M. Wearable sensors for clinical applications in epilepsy, Parkinson's disease, and stroke: A mixed-methods systematic review. J. Neurol. 2018, 265, 1740-1752. [CrossRef] [PubMed]

18. Shanahan, C.J.; Boonstra, F.M.C.; Cofré Lizama, L.E.; Strik, M.; Moffat, B.A.; Khan, F.; Kilpatrick, T.J.; van der Walt, A.; Galea, M.P.; Kolbe, S.C. Technologies for Advanced Gait and Balance Assessments in People with Multiple Sclerosis. Front. Neurol. 2018, 8, 708. [CrossRef] [PubMed]

19. Patel, S.; Park, H.; Bonato, P.; Chan, L.; Rodgers, M. A review of wearable sensors and systems with application in rehabilitation. J. Neuroeng. Rehabil. 2012, 9, 21. [CrossRef] [PubMed]

20. Bensona, L.C.; Clermonta, C.A.; Bošnjaka, E.; Ferber, R. The use of wearable devices for walking and running gait analysis outside of the lab: A systematic review. Gait Posture 2018, 63, 124-138. [CrossRef] [PubMed]

21. Chan, M.; Estève, D.; Fourniols, J.Y.; Escriba, C.; Campo, E. Smart wearable systems: Current status and future challenges. Artif. Intell. Med. 2012, 56, 137-156. [CrossRef] [PubMed]

22. Lymberis, A. Research and development of smart wearable health applications: The challenge ahead. Stud. Health Technol. Inform. 2004, 108, 155-161. [PubMed]

23. Cook, D.J.; Augusto, J.C.; Jakkula, V.R. Ambient intelligence: Technologies, applications, and opportunities. Pervasive Mob. Comput. 2009, 5, 277-298. [CrossRef]

24. Spyropoulos, E.; Chroni, E.; Katsakiori, P.; Athanassiou, G. A quantitative approach to assess upper limb fatigue in the work field. Occup. Ergon. 2013, 11, 45-57.

25. David, G. Ergonomic methods for assessing exposure to risk factors for workrelated musculoskeletal disorders. Occup. Ergon. 2005, 55, 190-199. [CrossRef] [PubMed]

26. Søgaard, K.; Laursen, B.; Jensen, B.R.; Sjøgaard, G. Dynamic loads on the upper extremities during two different floor cleaning methods. Clin. Biomech. 2001, 16, 866-879. [CrossRef]

27. Grant, M.J.; Booth, A. A typology of reviews: An analysis of 14 review types and associated methodologies. Health Inf. Libr. J. 2009, 26, 91-108. [CrossRef] [PubMed]

28. Bureau of Labor Statistics (BLS). Nonfatal Occupational Injuries and Illnesses Requiring Days Away from Work, 2015; Bureau of Labor Statistics: Washington, DC, USA, 2016.

29. Spector, J.T.; Lieblich, M.; Bao, S.; McQuade, K.; Hughes, M. Automation of Workplace Lifting Hazard Assessment for Musculoskeletal Injury Prevention. Ann. Occup. Environ. Med. 2014, 26, 15. [CrossRef] [PubMed] 
30. Hussey, L.S.; Turner, K.; Thorley, R.; McNamee, R.; Agius, R. Work-related Sickness Absence as Reported by UK General Practitioners. Occup. Med. (Lond.) 2012, 62, 105-111. [CrossRef] [PubMed]

31. Palmer, K.T.; Harris, E.C.; Linaker, C.; Barker, M.; Lawrence, W.; Cooper, C.; Coggond, D. Effectiveness of Community- and Workplace-Based Interventions to Manage Musculoskeletal-Related Sickness Absence and Job Loss: A Systematic Review. Rheumatology (Oxford) 2012, 51, 230-242. [CrossRef] [PubMed]

32. Linaker, C.; Harris, E.C.; Cooper, C.; Coggon, D.; Palmer, K.T. The Burden of Sickness Absence from Musculoskeletal Causes in Great Britain. Occup. Med. (Lond.) 2011, 61, 458-464. [CrossRef] [PubMed]

33. HSE (Health and Safety Executive). Self-Reported Work-Related Illness (SWI) and Workplace Injuries: Results from the Labour Force Survey (LFS)_Index of Tables. 2011. Available online: http:/ / www.hse.gov. uk/statistics/lfs/index.htm (accessed on 13 December 2017).

34. da Costa, B.R.; Vieira, E.R. Risk Factors for Work-related Musculoskeletal Disorders: A Systematic Review of Recent Longitudinal Studies. Am. J. Ind. Med. 2010, 53, 285-323. [CrossRef] [PubMed]

35. European Foundation for the Improvement of Living and Working Conditions (EFILWC). Fourth European Working Conditions Survey; European Foundation for the Improvement of Living and Working Conditions: Dublin, Ireland, 2007; ISBN 92-897-0974-X.

36. Buckle, P. Ergonomics and Musculoskeletal Disorders: Overview. Occup. Med. (Lond.) 2005, 55, $164-167$. [CrossRef] [PubMed]

37. Guo, H.R.; Chang, Y.C.; Yeh, W.Y.; Chen, C.W.; Guo, Y.L. Prevalence of Musculoskeletal Disorder Among Workers in Taiwan: Anationwide Study. J. Occup. Health 2004, 46, 26-36. [CrossRef] [PubMed]

38. Buckle, P.W.; Devereux, J.J. The Nature of Work-related Neck and Upper Limb Musculoskeletal Disorders. Appl. Ergon. 2002, 33, 207-217. [CrossRef]

39. Punnett, L.; Wegman, D.H. Work-related Musculoskeletal Disorders: The Epidemiologic Evidence and the Debate. J. Electromyogr. Kinesiol. 2004, 14, 13-23. [CrossRef] [PubMed]

40. Picavet, H.S.; Schouten, J.S. Musculoskeletal Pain in The Netherlands: Prevalences, Consequences and Risk Groups, the DMC(3)-Study. Pain 2003, 102, 67-78. [CrossRef]

41. Thiehoff, R. Economic Significance of Work Disability Caused by Musculoskeletal Disorders. Orthopade 2002, 31, 949-956. [CrossRef] [PubMed]

42. Leigh, J.; Macaskill, P.; Kuosma, E.; Mandryk, J. Global Burden of Diseases and Injuries Due to Occupational Factors. Epidemiology 1999, 10, 626-631. [CrossRef] [PubMed]

43. Van Hoof, W.; O'Sullivan, K.; O'Keeffe, M.; Verschueren, S.; O'Sullivan, P.; Dankaerts, W. The efficacy of interventions for low back pain in nurses: A systematic review. Int. J. Nurs. Stud. 2018, 77, 222-231. [CrossRef] [PubMed]

44. Kim, K.H.; Kim, K.S.; Kim, D.S.; Jang, S.J.; Hong, K.H.; Yoo, S.W. Characteristics of work-related musculoskeletal disorders in Korea and their work-relatedness evaluation. J. Korean Med. Sci. 2010, 25, S77-S86. [CrossRef] [PubMed]

45. Guo, H.R.; Tanaka, S.; Cameron, L.L.; Seligman, P.J.; Behrens, V.J.; Ger, J.; Wild, D.K.; Putz-Anderson, V. Back Pain Among Workers in the United States: National Estimates and Workers at High Risk. Am. J. Ind. Med. 1995, 28, 591-602. [CrossRef] [PubMed]

46. Guo, H.R.; Tanaka, S.; Halperin, W.E.; Cameron, L.L. Back Pain Prevalence in US Industry and Estimates of Lost Workdays. Am. J. Public Health 1999, 89, 1029-1035. [CrossRef] [PubMed]

47. Waters, T.R.; Baron, S.L.; Kemmlert, K. Accuracy of Measurements for the Revised NIOSH Lifting Equation. National Institute for Occupational Safety and Health. Appl. Ergon. 1998, 29, 433-438. [CrossRef]

48. Waters, T.R.; Baron, S.L.; Piacitelli, L.; Anderson, V.; Skov, T.; Haring-Sweeney, M.; Wall, D.K.; Fine, L.J. Evaluation of the Revised NIOSH Lifting Equation. Spine 1999, 24, 386-395. [CrossRef] [PubMed]

49. Waters, T.R.; Putz-Anderson, V.; Garg, A.; Fine, L.J. Revised NIOSH Equation for the Design and Evaluation of Manual Lifting Tasks. Ergonomics 1993, 36, 749-776. [CrossRef] [PubMed]

50. Waters, T.R.; Putz-Anderson, V.; Garg, A. Applications Manual for the Revised NIOSH Lifting Equation; U.S. Department of Health and Human Services: Cincinnati, OH, USA, 1994.

51. National Safety Council (NSC). Accident Facts; NSC: Chicago, IL, USA, 1990.

52. Huisstede, B.M.; Bierma-Zeinstra, S.M.; Koes, B.W.; Verhaar, J.A. Incidence and prevalence of upper-extremity musculoskeletal disorders. A systematic appraisal of the literature. BMC Musculoskelet. Disord. 2006, 7, 7. [CrossRef] [PubMed] 
53. GBD 2016 Risk Factors Collaborators. Global, regional, and national comparative risk assessment of 84 behavioural, environmental and occupational, and metabolic risks or clusters of risks, 1990-2016: A systematic analysis for the Global Burden of Disease Study 2016. Lancet 2017, 16, 390, 1345-1422.

54. INAIL, Italian Worker's Compensation Authority. Annual Report. Part IV. Statistics, Accidents and Occupational Diseases. 2016. Available online: https://www.inail.it/cs/internet/docs/alg-relazionedel-presidente-appendice-statistica-2016pdf.pdf (accessed on 5 December 2017).

55. McGill, S.M. The biomechanics of low back injury: Implications on current practices in industry and the clinic. J. Biomech. 1999, 30, 465-475. [CrossRef]

56. Norman, R.W.; Wells, R.; Neumann, P.; Frank, J.; Shannon, H.; Kerr, M. A comparison of peak vs. cumulative physical work exposure risk factors for the reporting of low back pain in the automotive industry. Clin. Biomech. 1998, 13, 561-573. [CrossRef]

57. Granata, K.P.; Marras, W.S. Cost-benefit of muscle cocontraction in protecting against spinal instability. Spine (Phila PA 1976) 2000, 25, 1398-1404. [CrossRef]

58. Ranavolo, A.; Chini, G.; Silvetti, A.; Mari, S.; Serrao, M.; Draicchio, F. Myoelectric manifestation of muscle fatigue in repetitive work detected by means of miniaturized sEMG sensors. Int. J. Occup. Saf. Ergon. 2017, 25, 1-11. [CrossRef] [PubMed]

59. Kim, E.A.; Nakata, M. Work-related Musculoskeletal Disorders in Korea and Japan: A Comparative Description. Ann. Occup. Environ. Med. 2014, 26, 17. [CrossRef] [PubMed]

60. Cifrek, M.; Medved, V.; Tonkovi'c, S.; Ostojić, S. Surface EMG based muscle fatigue evaluation in biomechanics. Clin. Biomech. 2009, 24, 327-340. [CrossRef] [PubMed]

61. Colombini, D.; Occhipinti, E. Preventing upper limb work-related musculoskeletal disorders (UL-WMSDS): New approaches in job (re)design and current trends in standardization. Appl. Ergon. 2006, 37, 441-450. [CrossRef] [PubMed]

62. Marras, W.S. The complex spine: The multidimensional system of causal pathways for low-back disorders. Hum. Factors 2012, 54, 881-889. [CrossRef] [PubMed]

63. Dickerson, C.R.; Meszaros, K.A.; Cudlip, A.C.; Chopp-Hurley, J.N.; Langenderfer, J.E. The influence of cycle time on shoulder fatigue responses for a fixed total overhead workload. J. Biomech. 2015, 48, 2911-2918. [CrossRef] [PubMed]

64. Argubi-Wollesen, A.; Wollesen, B.; Leitner, M.; Mattes, K. Human Body Mechanics of Pushing and Pulling: Analyzing the Factors of Task-related Strain on the Musculoskeletal System. Saf. Health Work 2017, 8, 11-18. [CrossRef] [PubMed]

65. Le, P.; Aurand, A.; Dufour, J.S.; Knapik, G.G.; Best, T.M.; Khan, S.N.; Mendel, E.; Marras, W.S. Development and testing of a moment-based coactivation index to assess complex dynamic tasks for the lumbar spine. Clin. Biomech. 2017, 46, 23-32. [CrossRef] [PubMed]

66. Le, P.; Best, T.M.; Khan, S.N.; Mendel, E.; Marras, W.S. A review of methods to assess coactivation in the spine. J. Electromyogr. Kinesiol. 2017, 32, 51-60. [CrossRef] [PubMed]

67. Anderson, S.P.; Oakman, J. Allied Health Professionals and Work-Related Musculoskeletal Disorders: A Systematic Review. Saf. Health Work 2016, 7, 259-267. [CrossRef] [PubMed]

68. Waters, T.R.; Lu, M.; Piacitelli, L.A.; Werren, D.; Deddens, J.A. Efficacy of the revised NIOSH lifting equation to predict low back pain due to manual lifting: Expanded crosssectional analysis. J. Occup. Environ. Med. 2011, 53, 1061-1067. [CrossRef] [PubMed]

69. Marras, W.S.; Lavender, S.A.; Ferguson, S.A.; Splittstoesser, R.E.; Yang, G. Quantitative dynamic measures of physical exposure predict low back functional impairment. Spine 2010, 35, 914-923. [CrossRef] [PubMed]

70. Marras, W.S.; Lavender, S.A.; Ferguson, S.A.; Splittstoesser, R.E.; Yang, G. Quantitative biomechanical workplace exposure measures: Distribution centers. J. Electromyogr. Kinesiol. 2010, 20, 813-822. [CrossRef] [PubMed]

71. Marras, W.S.; Fine, L.J.; Ferguson, S.A.; Waters, T.R. The effectiveness of commonly used lifting assessment methods to identify industrial jobs associated with elevated risk of low-back disorders. Ergonomics 1999, 42, 229-245. [CrossRef] [PubMed]

72. Marras, W.S.; Knapik, G.G.; Ferguson, S. Loading along the lumbar spine as influence by speed, control, load magnitude, and handle height during pushing. Clin. Biomech. 2009, 24, 155-163. [CrossRef] [PubMed]

73. Kong, Y.K.; Lowe, B.D. Optimal cylindrical handle diameter for grip force tasks. Int. J. Ind. Ergon. 2005, 35, 495-507. [CrossRef] 
74. Hoozemans, M.J.; Kuijer, P.P.; Kingma, I.; Van Dieen, J.H.; de Vries, W.H.; Van Der Woude, L.H.; Veeger, D.J.; Van Der Beek, A.J.; Frings-Dresen, M.H. Mechanical loading of the low back and shoulders during pushing and pulling activities. Ergonomics 2004, 47, 1-18. [CrossRef] [PubMed]

75. Hoozemans, M.J.; Van Der Beek, A.J.; Fring-Dresen, M.H.; Van Der Woude, L.H.; Van Dijk, F.J. Low-back and shoulder complaints among workers with pushing and pulling tasks. Scand. J. Work Environ. Health 2002, 28, 293-303. [CrossRef] [PubMed]

76. Hoozemans, M.J.; Van Der Beek, A.J.; Frings-Dresen, M.H.; Van Der Woude, L.H.; Van Dijk, F.J. Pushing and pulling in association with low back and shoulder complaints. Occup. Environ. Med. 2002, 59, 696-702. [CrossRef] [PubMed]

77. ISO 11228-2. Ergonomics-Manual Handling_Part 2: Pushing and Pulling; ISO: Geneva, Switzerland, 2007.

78. ISO/DIS 11228-1. Ergonomics_Manual Handling_Part 1: Lifting and Carrying; ISO: Geneva, Switzerland, 2003.

79. ISO/DIS 11228-3. Ergonomics-Manual Handling_Part 3: Handling of Low Loads at High Frequency; ISO: Geneva, Switzerland, 2007.

80. ISO/TR 12295. Ergonomics-Application Document for ISO Standards on Manual Handling (ISO 11228-1, ISO 11228-2 and ISO 11228-3) and Static Working Postures (ISO 11226); ISO: Geneva, Switzerland, 2004.

81. ISO 11226. Ergonomics_Evaluation of Static Working Postures; ISO: Geneva, Switzerland, 2000.

82. ISO/TR 12296. Ergonomics-Manual Handling of People in the Healthcare Sector; ISO: Geneva, Switzerland, 2012.

83. Li, G.; Buckle, P. Evaluating Change in Exposure to Risk for Musculoskeletal Disordersea Practical Tool. HSE Books, Suffolk [Online]. 1999; 74p, CRR251. Available online: http://www.hse.gov.uk/research/crr_pdf/ 1999/ crr99251.pdf (accessed on 27 October 2005).

84. Vignais, N.; Miezal, M.; Bleser, G.; Mura, K.; Gorecky, D.; Marin, F. Innovative system for real-time ergonomic feedback in industrial manufacturing. Appl. Ergon. 2013, 44, 566-574. [CrossRef] [PubMed]

85. Dempsey, P.G.; Burdorf, A.; Fathallah, F.A.; Sorock, G.S.; Hashemi, L. Influence of measurement accuracy on the application of the 1991 NIOSH equation. Appl. Ergon. 2001, 32, 91-99. [CrossRef]

86. Dempsey, P.G. Usability of the revised NIOSH lifting equation. Ergonomics 2002, 45, 817-828. [CrossRef] [PubMed]

87. Jones, T.; Kumar, S. Comparison of ergonomic risk assessment output in four sawmill jobs. Int. J. Occup. Saf. Ergon. 2010, 16, 105-111. [CrossRef] [PubMed]

88. Spielholz, P.; Bao, S.; Howard, N.; Silverstein, B.; Fan, J.; Smith, C.; Salazar, C. Reliability and validity assessment of the hand activity level threshold limit value and strain index using expert ratings of mono-task jobs. J. Occup. Environ. Hyg. 2008, 5, 250-257. [CrossRef] [PubMed]

89. Waters, T.R.; Dick, R.B.; Davis-Barkley, J.; Krieg, E.F. A cross-sectional study of risk factors for musculoskeletal symptoms in the workplace using data from the General Social Survey (GSS). J. Occup. Environ. Med. 2007, 49, 172-184. [CrossRef] [PubMed]

90. Bao, S.; Spielholz, P.; Howard, N.; Silverstein, B. Quantifying repetitive hand activity for epidemiological research on musculoskeletal disorders-Part I: Individual exposure assessment. Ergonomics 2006, 49, 361-380. [CrossRef] [PubMed]

91. Bao, S.; Howard, N.; Spielholz, P.; Silverstein, B. Quantifying repetitive hand activity for epidemiological research on musculoskeletal disorders-Part II: Comparison of different methods of measuring force level and repetitiveness. Ergonomics 2006, 49, 381-392. [CrossRef] [PubMed]

92. Flegal, K.M.; Keyl, P.M.; Nieto, F.J. Differential misclassification arising from non-differential errors in exposure measurement. Am. J. Epidemiol. 1991, 134, 1233-1244. [CrossRef] [PubMed]

93. Shanahan, C.J.; Vi, P.; Salas, E.A.; Reider, V.L.; Hochman, L.M.; Moore, A.E. A comparison of RULA, REBA and Strain Index to four psychophysical scales in the assessment of non-fixed work. Work 2013, 45, 367-378. [PubMed]

94. Paulsen, R.; Gallu, T.; Gilkey, D.; Reiser, R., 2nd.; Murgia, L.; Rosecrance, J. The inter-rater reliability of Strain Index and OCRA Checklist task assessments in cheese processing. Appl. Ergon. 2015, 51, 199-204. [CrossRef] [PubMed]

95. Li, G.; Buckle, P. The Development of a Practical Method for the Exposure Assessment of Risks to Work-Related Musculoskeletal Disorders; General Report to the HSE (Contract No. R3408); Robens Centre for Health Ergonomics, European Institute of Health and Medical Sciences, University of Surrey: Guildford, UK, 1999.

96. Wang, Q.; Markopoulos, P.; Yu, B.; Chen, W.; Timmermans, A. Interactive wearable systems for upper body rehabilitation: A systematic review. J. Neuroeng. Rehabil. 2017, 14, 20. [CrossRef] [PubMed] 
97. Cuesta-Vargas, A.I.; Galán-Mercant, A.; Williams, J.M. The use of inertial sensors system for human motion analysis. Phys. Ther. Rev. 2013, 15, 462-473. [CrossRef] [PubMed]

98. Ullah, S.; Higgins, H.; Braem, B.; Latre, B.; Blondia, C.; Moerman, I.; Saleem, S.; Rahman, Z.; Kwak, K.S. A comprehensive survey of wireless body area networks. J. Med. Syst. 2012, 36, 1065-1094. [CrossRef] [PubMed]

99. Fong, D.; Chan, Y.Y. The use of wearable inertial motion sensors in human lower limb biomechanics studies: A systematic review. Sensors 2010, 10, 11556-11565. [CrossRef] [PubMed]

100. Breen, P.P.; Nisar, A.; Olaighin, G. Evaluation of a single accelerometer based biofeedback system for real-time correction of neck posture in computer users. In Proceedings of the IEEE Engineering in Medicine and Biology Society Annual International Conference, Minneapolis, MN, USA, 2-6 September 2009; pp. 7269-7272.

101. Roetenberg, D.; Luinge, H.; Slycke, P. Xsens MVN: Full 6DOF Human Motion Tracking Using Miniature Inertial Sensors; Technical Report; Xsens Technologies B.V.: Enschede, The Netherlands, 2009.

102. Bonato, P. Advances in wearable technology and applications in physical medicine and rehabilitation. J. Neuroeng. Rehabil. 2005, 2, 2. [CrossRef] [PubMed]

103. Trask, C.; Teschke, K.; Village, J.; Chow, Y.; Johnson, P.; Luong, N.; Koehoorn, M. Measuring low back injury risk factors in challenging work environments: An evaluation of cost and feasibility. Am. J. Ind. Med. 2007, 50, 687-696. [CrossRef] [PubMed]

104. Mogk, J.P.; Keir, P.J. Prediction of forearm muscle activity during gripping. Ergonomics 2006, 49, 1121-1130. [CrossRef] [PubMed]

105. Iosa, M.; Picerno, P.; Paolucci, S.; Morone, G. Wearable inertial sensors for human movement analysis. Expert Rev. Med. Devices 2016, 13, 641-659. [CrossRef] [PubMed]

106. Rodríguez-Martín, D.; Pérez-López, C.; Samà, A.; Català, A.; Moreno Arostegui, J.M.; Cabestany, J.; Mestre, B.; Alcaine, S.; Prats, A.; Cruz Crespo, M.; et al. A Waist-Worn Inertial Measurement Unit for Long-Term Monitoring of Parkinson's Disease Patients. Sensors (Basel) 2017, 17, 827. [CrossRef] [PubMed]

107. Lovett, R.W.; Martin, E.G. The spring balance muscle test. Am. J. Orthop. Surg. 1916, 14, 415-424.

108. Park, H.W.; Baek, S.; Kim, H.Y.; Park, J.G.; Kang, E.K. Reliability and Validity of a New Method for Isometric Back Extensor Strength Evaluation Using A Hand-Held Dynamometer. Ann. Rehabil. Med. 2017, 41, 793-800. [CrossRef] [PubMed]

109. Jackson, S.M.; Cheng, M.S.; Smith, A.R., Jr.; Kolber, M.J. Intrarater reliability of handheld dynamometry in measuring lower extremity isometric strength using a portable stabilization device. Musculoskelet. Sci. Pract. 2017, 27, 137-141. [CrossRef] [PubMed]

110. Karthikbabu, S.; Chakrapani, M. Hand-Held Dynamometer is a Reliable Tool to Measure Trunk Muscle Strength in Chronic Stroke. J. Clin. Diagn. Res. 2017, 11, YC09-YC12. [CrossRef] [PubMed]

111. Andersen, K.S.; Christensen, B.H.; Samani, A.; Madeleine, P. Between-day reliability of a hand-held dynamometer and surface electromyography recordings during isometric submaximal contractions in different shoulder positions. J. Electromyogr. Kinesiol. 2014, 245, 579-587. [CrossRef] [PubMed]

112. Stark, T.; Walker, B.; Phillips, J.K.; Fejer, R.; Beck, R. Hand-held dynamometry correlation with the gold standard isokinetic dynamometry: A systematic review. PM R 2011, 3, 472-479. [CrossRef] [PubMed]

113. Fulcher, M.L.; Hanna, C.M.; Raina Elley, C. Reliability of handheld dynamometry in assessment of hip strength in adult male football players. J. Sci. Med. Sport 2010, 13, 80-84. [CrossRef] [PubMed]

114. Roy, J.S.; MacDermid, J.C.; Orton, B.; Tran, T.; Faber, K.J.; Drosdowech, D.; Athwal, G.S. The concurrent validity of a hand-held versus a stationary dynamometer in testing isometric shoulder strength. J. Hand Ther. 2009, 22, 320-326. [CrossRef] [PubMed]

115. Holt, K.L.; Raper, D.P.; Boettcher, C.E.; Waddington, G.S.; Drew, M.K. Hand-held dynamometry strength measures for internal and external rotation demonstrate superior reliability, lower minimal detectable change and higher correlation to isokinetic dynamometry than externally-fixed dynamometry of the shoulder. Phys. Ther. Sport 2016, 21, 75-81. [CrossRef] [PubMed]

116. Edgren, C.S.; Radwin, R.G.; Irwin, C.B. Grip force vectors for varying handle diameters and hand sizes. Hum. Factors 2004, 46, 244-251. [CrossRef] [PubMed]

117. McGorry, R.W. A system for the measurement of grip forces and applied moments during hand tool use. Appl. Ergon. 2001, 32, 271-279. [CrossRef]

118. Fowler, N.K.; Nicol, A.C. A force transducer to measure individual finger loads during activities of daily living. J. Biomech. 1999, 32, 721-725. [CrossRef] 
119. Radwin, R.G.; Masters, G.P.; Lupton, F.W. A linear force-summing hand dynamometer independent of point of application. Appl. Ergon. 1991, 22, 339-345. [CrossRef]

120. Amis, A.A. Variation of finger forces in maximal isometric grasp tests on a range of cylinder diameters. J. Biomed. Eng. 1987, 9, 313-320. [CrossRef]

121. Seo, N.; Armstrong, T.; Ashton-Miller, J.; Chaffin, D. The effect of torque direction and cylindrical handle diameter on the coupling between the hand and a cylindrical handle. J. Biomech. 2007, 40, 3236-3243. [CrossRef] [PubMed]

122. Seo, N.; Armstrong, T. Investigation of grip force, normal force, contact area, hand size, and handle size for cylindrical handles. Hum. Factors 2008, 50, 734-744. [CrossRef] [PubMed]

123. Kong, Y.K.; Freivalds, A.; Kim, S.E. Evaluation of handles in a maximum gripping task. Ergonomics 2004, 47, 1350-1364. [CrossRef] [PubMed]

124. Kong, Y.K.; Freivalds, A. Evaluation of meat-hook handle shapes. Int. J. Ind. Ergon. 2003, 32, $13-23$. [CrossRef]

125. Hall, C. External pressure at the hand during object handling and work with tools. Int. J. Ind. Ergon. 1997, 20, 191-206. [CrossRef]

126. Radwin, R.G.; Oh, S.; Jensen, T.R.; Webster, J.G. External finger forces in submaximal static prehension. Ergonomics 1992, 35, 275-288. [CrossRef] [PubMed]

127. Irwin, C.B.; Towles, J.D.; Radwin, R.G. Development and Application of a Multi-Axis Dynamometer for Measuring Grip Force. Ergonomics 2013, 56, 1841-1849. [CrossRef] [PubMed]

128. Irwin, C.B.; Sesto, M.E. Reliability and validity of the multiaxis profile dynamometer with younger and older participants. J. Hand Ther. 2010, 23, 281-288. [CrossRef] [PubMed]

129. Tyler, T.F.; Nahow, R.C.; Nahow, R.C.; Nicholas, S.J.; McHugh, M.P. Quantifying shoulder rotation weakness in patients with shoulder impingement. J. Shoulder Elb. Surg. 2005, 14, 570-574. [CrossRef] [PubMed]

130. Ellenbecker, T.S. Muscular strength relationship between normal grade manual muscle testing and isokinetic measurement of shoulder internal and external rotators. Isokinet Exerc. Sci. 1996, 6, 51-56.

131. Hayes, K.; Walton, J.; Szomor, Z.L.; Murrell, G.A.C. Reliability of 3 methods for assessing shoulder strength. J. Shoulder Elb. Surg. 2002, 11, 33-39. [CrossRef] [PubMed]

132. Leggin, B.G.; Neuman, R.M.; Iannotti, J.P.; Williams, G.R.; Thompson, E.C. Intrarater and interrater reliability of three isometric dynamometers in assessing shoulder strength. J. Shoulder Elb. Surg. 1996, 5, 18-24. [CrossRef]

133. Covarrubias, M.; Bordegoni, M.; Cugini, U. Force Sensitive Handles and Capacitive Touch Sensor for Driving a Flexible Haptic-Based Immersive System. Sensors 2013, 13, 13487-13508. [CrossRef] [PubMed]

134. Bordegoni, M.; Cugini, U.; Covarrubias, M.; Antolini, M. Geodesic Haptic Device for Surface Rendering. In Proceedings of the Joint Virtual Reality Conference of EGVE-ICAT-EuroVR 2009, Lyone, France, 7-9 December 2009.

135. Bordegoni, M.; Ferrise, F.; Covarrubias, M.; Antolini, M. A Linear Interface for the Evaluation of Shapes. In Proceedings of the ASME 2009 International Design Engineering Technical Conferences \& Computers and Information in Engineering Conference (IDETC/CIE 2009), San Diego, CA, USA, 30 August 2009.

136. Gazzoni, M. Multichannel Surface Electromyography in Ergonomics: Potentialities and Limits. Hum. Factors Ergon. Manuf. Serv. Ind. 2010, 20, 255-271. [CrossRef]

137. Hägg, G.M.; Luttmann, A.; Jäger, M. Methodologies for evaluating electromyographic field data in ergonomics. J. Electromyogr. Kinesiol. 2000, 10, 301-312. [CrossRef]

138. Luttmann, A.; Jäger, M.; Laurig, W. Electromyographical indication of muscular fatigue in occupational field studies. Int. J. Ind. Ergon. 2000, 25, 645-660. [CrossRef]

139. Luttmann, A.; Jäger, M.; Sökeland, J.; Laurig, W. Electromyographical study on surgeons in urology, part II: Determination of muscular fatigue. Ergonomics 1996, 39, 298-313. [CrossRef] [PubMed]

140. Kumar, S.; Mital, A. (Eds.) Electromyography in Ergonomics; Taylor and Francis: London, UK, 1996.

141. Mathiassen, S.E.; Winkel, J.; Hägg, G.M. Normalization of surface EMG amplitude from the upper trapezius muscle in ergonomic studies-A review. J. Electromyogr. Kinesiol. 1995, 5, 197-226. [CrossRef]

142. Severini, G.; Conforto, S.; Schmid, M.; D'Alessio, T. Novel formulation of a double threshold algorithm for the estimation of muscle activation intervals designed for variable SNR environments. J. Electromyogr. Kinesiol. 2012, 22, 878-885. [CrossRef] [PubMed] 
143. Urquhart, D.M.; Hodges, P.W.; Story, I.H. Postural activity of the abdominal muscles varies between regions of these muscles and between body positions. Gait Posture 2005, 22, 295-301. [CrossRef] [PubMed]

144. Bogey, R.A.; Barnes, L.A.; Perry, J. Computer algorithms to characterize individual subject EMG profiles during gait. Arch. Phys. Med. Rehabil. 1992, 73, 835-841. [PubMed]

145. Bogey, R.A.; Perry, J.; Gitter, A.J. An EMG-to-force processing approach for determining ankle muscle forces during normal human gait. IEEE Trans. Neural Syst. Rehabil. Eng. 2005, 13, 302-310. [CrossRef] [PubMed]

146. Khalil, M.; Duchene, J. Uterine EMG analysis: A dynamic approach for change detection and classification. IEEE Trans. Biomed. Eng. 2000, 46, 748-756. [CrossRef] [PubMed]

147. Conforto, S. Processing Techniques for Myoelectric Surface Signal in Dynamic Conditions. Ph.D. Dissertation, Università di Bologna, Bologna, Italy, 1999.

148. van Putten, J.D., Jr. EMG onset determination using a maximum likelihood method. In Proceedings of the First Joint BMES/EMBS Conference, 1999 IEEE Engineering in Medicine and Biology 21st Annual Conference and the 1999 Annual Fall Meeting of the Biomedical Engineering Society, Atlanta, GA, USA, 13-16 October 1999; p. 571.

149. Bonato, P.; D'Alessio, T.; Knaflitz, M. A statistical method for the measurement of muscle activation intervals from surface myoelectric signal during gait. IEEE Trans. Biomed. Eng. 1998, 45, 287-299. [CrossRef] [PubMed]

150. Micera, S.; Sabatini, A.M.; Dario, P. An algorithm for detecting the onset of muscle contraction by EMG signal processing. Med. Eng. Phys. 1998, 20, 211-215. [CrossRef]

151. Staudenmann, D.; Roeleveld, K.; Stegeman, D.F.; van Dieën, J.H. Methodological aspects of SEMG recordings for force estimation-A tutorial and review. J. Electromyogr. Kinesiol. 2010, 20, 375-387. [CrossRef] [PubMed]

152. Vannozzi, G.; Conforto, S.; D'Alessio, T. Automatic detection of surface EMG activation timing using a wavelet transform based method. J. Electromyogr. Kinesiol. 2010, 20, 767-772. [CrossRef] [PubMed]

153. Vaisman, L.; Zariffa, J.; Popovic, M.R. Application of singular spectrum-based change-point analysis to EMG-onset detection. J. Electromyogr. Kinesiol. 2010, 20, 750-760. [CrossRef] [PubMed]

154. Merlo, A.; Farina, D.; Merletti, R. A fast and reliable technique for muscle activity detection from surface EMG signals. IEEE Trans. Biomed. Eng. 2003, 50, 316-323. [CrossRef] [PubMed]

155. Merletti, R.; Knaflitz, M.; De Luca, C.J. Myoelectric manifestations of fatigue in voluntary and electrically elicited contractions. J. Appl. Physiol. 1990, 69, 1810-1820. [CrossRef] [PubMed]

156. Ranavolo, A.; Mari, S.; Conte, C.; Serrao, M.; Silvetti, A.; Iavicoli, S.; Draicchio, F. A new muscle co-activation index for biomechanical load evaluation in work activities. Ergonomics 2015, 58, 966-979. [CrossRef] [PubMed]

157. Martinez-Valdes, E.; Laine, C.M.; Falla, D.; Mayer, F.; Farina, D. High-density surface electromyography provides reliable estimates of motor unit behavior. Clin. Neurophysiol. 2016, 127, 2534-2541. [CrossRef] [PubMed]

158. Stegeman, D.F.; Kleine, B.U.; Lapatki, B.J.; van Dijk, J.P. High-density Surface EMG: Techniques and Applications at a Motor Unit Level. Biocybern. Biomed. Eng. 2012, 32, 3-27.

159. Maathuis, E.M.; Drenthen, J.; van Dijk, J.P.; Visser, G.H.; Blok, J.H. Motor unit tracking with high-density surface EMG. J. Electromyogr. Kinesiol. 2008, 18, 920-930. [CrossRef] [PubMed]

160. Merletti, R.; Botter, A.; Troiano, A.; Merlo, E.; Minetto, M.A. Technology and instrumentation for detection and conditioning of the surface electromyographic signal: State of the art. Clin. Biomech. 2009, 24, 122-134. [CrossRef] [PubMed]

161. Merletti, R.; Farina, D.; Gazzoni, M. The linear electrode array: A useful tool with many applications. J. Electromyogr. Kinesiol. 2003, 13, 37-47. [CrossRef]

162. de Looze, M.; Bosch, T.; van Dieën, J. Manifestations of shoulder fatigue in prolonged activities involving low-force contractions. Ergonomics 2009, 52, 428-437. [CrossRef] [PubMed]

163. Bosch, T.; de Looze, M.P.; van Dieën, J.H. Development of fatigue and discomfort in the upper trapezius muscle during light manual work. Ergonomics 2007, 50, 161-177. [CrossRef] [PubMed]

164. Mathiassen, S.E.; Winkel, J. Physiological comparison of three interventions in light assembly work: Reduced work pace, increased break allowance and shortened working days. Int. Arch. Occup. Environ. Health 1996, 68, 94-108. [CrossRef] [PubMed]

165. Sundelin, G.; Hagberg, M. Electromyographic signs of shoulder muscle fatigue in repetitive arm work paced by the methods-time measurement system. Scand. J. Work Environ. Health 1992, 18, 262-268. [CrossRef] [PubMed] 
166. Sundelin, G. Patterns of electromyographic shoulder muscle fatigue during MTM-paced repetitive arm work with and without pauses. Int. Arch. Occup. Environ. Health 1993, 64, 485-493. [CrossRef] [PubMed]

167. Hansson, G.A.; Strömberg, U.; Larsson, B.; Ohlsson, K.; Balogh, I.; Moritz, U. Electromyographic fatigue in neck/shoulder muscles and endurance in women with repetitive work. Ergonomics 1992, 35, 1341-1352. [CrossRef] [PubMed]

168. Farina, D.; Merletti, R. A novel approach for estimating muscle fiber conduction velocity by spatial and temporal filtering of surface EMG signals. IEEE Trans. Biomed. Eng. 2003, 50, 1340-1351. [CrossRef] [PubMed]

169. Farina, D.; Merletti, R. Methods for estimating muscle fibre conduction velocity from surface electromyographic signals. Med. Biol. Eng. Comput. 2004, 42, 432-445, Erratum in Med. Biol. Eng. Comput. 2004, 42, 732. [CrossRef] [PubMed]

170. Farina, D.; Fortunato, E.; Merletti, R. Noninvasive estimation of motor unit conduction velocity distribution using linear electrode arrays. IEEE Trans. Biomed. Eng. 2000, 47, 380-388. [CrossRef] [PubMed]

171. Lindstrom, L.; Kadefor, R.; Petersen, I. An electromyographic index for localized muscle fatigue. J. Appl. Physiol. 1997, 43, 750-754. [CrossRef] [PubMed]

172. Harba, M.I.; Zaia, I.F.; Naief, A.K. Online measurement of muscle fibre conduction velocity: Analysis and optimization of performance. J. Biomed. Eng. 1988, 10, 33-46. [CrossRef]

173. Brandt, M.; Madeleine, P.; Samani, A.; Jakobsen, M.D.; Skals, S.; Vinstrup, J.; Andersen, L.L. Accuracy of identification of low or high risk lifting during standardized lifting situations. Ergonomics 2018, 61, 710-719. [CrossRef] [PubMed]

174. Ranavolo, A.; Varrecchia, T.; Rinaldi, M.; Silvetti, A.; Serrao, M.; Conforto, S.; Draicchio, F. Mechanical lifting energy consumption in work activities designed by means of the "revised NIOSH lifting equation". Ind. Health 2017, 55, 444-454. [CrossRef] [PubMed]

175. Le, P.; Aurand, A.; Best, T.M.; Khan, S.N.; Mendel, E.; Marras, W.S. An Exploratory Electromyography-Based Coactivation Index for the Cervical Spine. Hum. Factors 2018, 60, 68-79. [CrossRef] [PubMed]

176. Le, P.; Aurand, A.; Walter, B.A.; Best, T.M.; Khan, S.N.; Mendel, E.; Marras, W.S. Development of a lumbar EMG-based coactivation index for the assessment of complex dynamic tasks. Ergonomics 2018, 61, 381-389. [CrossRef] [PubMed]

177. Ranavolo, A.; Varrecchia, T.; Iavicoli, S.; Marchesi, A.; Rinaldi, M.; Serrao, M.; Conforto, S.; Cesarelli, M.; Draicchio, F. Surface electromyography for risk assessment in work activities designed using the "revised NIOSH lifting equation". Int. J. Ind. Ergon. 2018, 68, 34-45. [CrossRef]

178. Varrecchia, T.; De Marchis, C.; Rinaldi, M.; Draicchio, F.; Serrao, M.; Schmid, M.; Conforto, S.; Ranavolo, A. Lifting activity assessment using surface electromyographic features and neural networks. Int. J. Ind. Ergon. 2018, 66, 1-9. [CrossRef]

179. Shair, E.F.; Ahmad, S.A.; Marhaban, M.H.; Mohd Tamrin, S.B.; Abdullah, A.R. EMG Processing Based Measures of Fatigue Assessment during Manual Lifting. Biomed. Res. Int. 2017, 2017, 3937254. [CrossRef] [PubMed]

180. Zwarts, M.J.; Stegeman, D.F. Multichannel surface EMG: Basic aspects and clinical utility. Muscle Nerve 2003, 28, 1-17. [CrossRef] [PubMed]

181. Qin, J.; Lin, J.H.; Faber, G.S.; Buchholz, B.; Xu, X. Upper extremity kinematic and kinetic adaptations during a fatiguing repetitive task. J. Electromyogr. Kinesiol. 2014, 24, 404-411. [CrossRef] [PubMed]

182. Roman-Liu, D.; Tokarski, T.; Wójcik, K. Quantitative assessment of upper limb muscle fatigue depending on the conditions of repetitive task load. J. Electromyogr. Kinesiol. 2004, 14, 671-682. [CrossRef] [PubMed]

183. Bosch, T.; de Looze, M.P.; Kingma, I.; Visser, B.; van Dieën, J.H. Electromyographical manifestations of muscle fatigue during different levels of simulated light manual assembly work. J. Electromyogr. Kinesiol. 2009, 19, 246-256. [CrossRef] [PubMed]

184. Iridiastadi, H.; Nussbaum, M.A. Muscle fatigue and endurance during repetitive intermittent static efforts: Development of prediction models. Ergonomics 2006, 49, 344-360. [CrossRef] [PubMed]

185. Iridiastadi, H.; Nussbaum, M.A. Muscular fatigue and endurance during intermittent static efforts: Effects of contraction level, duty cycle, and cycle time. Hum. Factors 2006, 48, 710-720. [CrossRef] [PubMed]

186. Silvetti, A.; Mari, S.; Ranavolo, A.; Forzano, F.; Iavicoli, S.; Conte, C.; Draicchio, F. Kinematic and electromyographic assessment of manual handling on a supermarket green- grocery shelf. Work 2015, 51, 261-271. [CrossRef] [PubMed] 
187. Draicchio, F.; Silvetti, A.; Forzano, F.; Iavicoli, S.; Ranavolo, A. Kinematic analysis of post office employees' workstations. Work 2012, 41 (Suppl. 1), 2012-2016.

188. Draicchio, F.; Trebbi, M.; Mari, S.; Forzano, F.; Serrao, M.; Sicklinger, A.; Silvetti, A.; Iavicoli, S.; Ranavolo, A. Biomechanical evaluation of supermarket cashiers before and after a redesign of the checkout counter. Ergonomics 2012, 55, 650-669. [CrossRef] [PubMed]

189. Kadefors, R.; Areskoug, A.; Dahlman, S.; Kilbom, Å.; Sperling, L.; Wikström, L.; Oster, J. An approach to ergonomics evaluation of hand tools. Appl. Ergon. 1993, 24, 203-211. [CrossRef]

190. National Institute for Occupational Safety and Health. Muscoloskeletal Disorders and Workplace Factor; National Institute for Occupational Safety and Health: Pittsburgh, PA, USA, 1997; Chapter 5.

191. National Research Council. Musculoskeletal Disorders and the Workplace; National Academy Press: Washington, DC, USA, 2001.

192. Constant, C.R.; Murley, A.H.G. A clinical method of functional assessment of the shoulder. Clin. Orthop. Relat. Res. 1987, 214, 160-164. [CrossRef]

193. Cyriax, J.H. Textbook of orthopaedic medicine. In Diagnosis of Soft Tissue Lesions, 8th ed.; Balliere Tindall: Minneapolis, MN, USA, 1982; Volume 1, pp. 1-50.

194. Cadogan, A.; Laslett, M.; Hing, W.; McNair, P.; Williams, M. Reliability of a new hand-held dynamometer in measuring shoulder range of motion and strength. Manu. Ther. 2011, 16, 97-101. [CrossRef] [PubMed]

195. Lukowicz, P.; Ward, J.A.; Junker, H.; Stger, M.; Trster, G.; Atrash, A.; Starner, T. Recognizing workshop activity using body worn microphones and accelerometers. In Pervasive Computing; Ferscha, A., Mattern, F., Eds.; No. 3001 in Lecture Notes in Computer Science; Springer: Berlin/Heidelberg, Germany, 2004; pp. 18-32.

196. Zappi, P.; Lombriser, C.; Stiefmeier, T.; Farella, E.; Roggen, D.; Benini, L.; Trster, G. Activity recognition from on-body sensors: Accuracy-power trade-off by dynamic sensor selection. In Wireless Sensor Networks; Verdone, R., Ed.; Vol. 4913 of Lecture Notes in Computer Science; Springer: Berlin/Heidelberg, Germany, 2009; pp. 17-33.

197. Koskimaki, H.; Huikari, V.; Siirtola, P.; Laurinen, P.; Roning, J. Activity recognition using a wrist-worn inertial measurement unit: A case study for industrial assembly lines. In Proceedings of the 17th Mediterranean Conference on Control and Automation (MED '09), Thessaloniki, Greece, 24-26 June 2009; pp. 401-405.

198. Yan, X.; Li, H.; Li, A.R.; Zhang, H. Wearable IMU-based real-time motion warning system for construction workers' musculoskeletal disorders prevention. Autom. Constr. 2017, 74, 2-11. [CrossRef]

199. Lee, J.A.; Li, N.; Haines, C.S.; Kim, K.J.; Lepró, X.; Ovalle-Robles, R.; Kim, S.J.; Baughman, R.H. Electrochemically Powered, Energy-Conserving Carbon Nanotube Artificial Muscles. Adv. Mater. 2017, 29. [CrossRef] [PubMed]

200. Kim, S.; Nussbaum, M.A.; Jia, B. Low back injury risks during construction with prefabricated (panelised) walls: Effects of task and design factors. Ergonomics 2011, 54, 60-71. [CrossRef] [PubMed]

201. Nimbarte, A.D.; Aghazadeh, F.; Ikuma, L.H.; Harvey, C.M. Neck disorders among construction workers: Understanding the physical loads on the cervical spine during static lifting tasks. Ind. Health 2010, 48, 145-153. [CrossRef] [PubMed]

202. Jia, B.; Kim, S.; Nussbaum, M.A. An EMG-based model to estimate lumbar muscle forces and spinal loads during complex, high-effort tasks: Development and application to residential construction using prefabricated walls. Int. J. Ind. Ergon. 2011, 41, 437-446. [CrossRef]

203. Perez-Duarte, F.; Lucas-Hernandez, M.; Matos-Azevedo, A.; Sanchez-Margallo, J.; Díaz-Güemes, I.; Sanchez-Margallo, F. Objective analysis of surgeons ergonomy during laparoendoscopic single-site surgery through the use of surface electromyography and a motion capture data glove. Surg. Endosc. 2014, 28, 1314-1320. [CrossRef] [PubMed]

204. Cabeças, J.M. The risk of distal upper limb disorder in cleaners: A modified application of the strain index method. Int. J. Ind. Ergon. 2007, 37, 563-571. [CrossRef]

205. Blackwell, J.R.; Kornatz, K.W.; Heath, E.M. Effect of grip span on maximal grip force and fatigue of flexor digitorum superficialis. Appl. Ergon. 1999, 30, 401-405. [CrossRef]

206. Armstrong, T.J.; Burdorf, A.; Descatha, A.; Farioli, A.; Graf, M.; Horie, S.; Marras, W.S.; Potvin, J.R.; Rempel, D.; Spatari, G.; Takala, E.P.; et al. Scientific basis of ISO standards on biomechanical risk factors. Scand. J. Work Environ. Health 2018, 44, 323-329. [CrossRef] [PubMed]

207. Chiasson, M.E.; Imbeau, D.; Aubry, K.; Delisle, A. Comparing the results of eight methods used to evaluate risk factors associated with musculoskeletal disorders. Int. J. Ind. Ergon. 2012, 42, 478-488. [CrossRef] 
208. Peppoloni, L.; Filippeschi, A.; Ruffaldi, E. Assessment of task ergonomics with an upper limb wearable device. In Proceedings of the 22nd Mediterranean Conference on Control and Automation, Palermo, Italy, 16-19 June 2014.

209. Hegde, N.; Bries, M.; Sazonov, E. A Comparative Review of Footwear-Based Wearable Systems. Electronics 2016, 5, 48. [CrossRef]

210. Moufawad, E.L.; Achkar, C.; Lenbole-Hoskovec, C.; Paraschiv-Ionescu, A.; Major, K.; Büla, C.; Aminian, K. Classification and characterization of postural transitions using instrumented shoes. Med. Biol. Eng. Comput. 2018, 56, 1403-1412. [CrossRef] [PubMed]

211. Liu, K.; Liu, Y.; Yan, J.; Sun, Z. Nondestructive Estimation of Muscle Contributions to STS Training with Different Loadings Based on Wearable Sensor System. Sensors (Basel) 2018, 18, 971.

212. Liu, T.; Inoue, Y.; Shibata, K. A wearable ground reaction force sensor system and its application to the measurement of extrinsic gait variability. Sensors 2010, 10, 10240-10255. [CrossRef] [PubMed]

213. Mirvakili, S.M.; Hunter, I.W. Artificial Muscles: Mechanisms, Applications, and Challenges. Adv. Mater. 2018, 30. [CrossRef] [PubMed]

214. Miriyev, A.; Stack, K.; Lipson, H. Soft material for soft actuators. Nat. Commun. 2017, 8, 596. [CrossRef] [PubMed]

215. Furukawa, J.; Noda, T.; Teramae, T.; Morimoto, J. An EMG-Driven Weight Support System with Pneumatic Artificial Muscles. IEEE Syst. J. 2014, 10, 1026-1034. [CrossRef]

216. Maziz, A.; Concas, A.; Khaldi, A.; Stålhand, J.; Persson, N.K.; Jager, E.W. Knitting and weaving artificial muscles. Sci. Adv. 2017, 3, e1600327. [CrossRef] [PubMed]

217. Totah, D.; Ojeda, L.; Johnson, D.D.; Gates, D.; Mower Provost, E.; Barton, K. Low-back electromyography (EMG) data-driven load classification for dynamic lifting tasks. PLoS ONE 2018, 13, e0192938. [CrossRef] [PubMed]

218. Merletti, R.; Parker, P.J. Electromyography: Physiology, Engineering, and Non-Invasive Applications; Wiley-IEEE Press: Hoboken, NJ, USA, 2004.

219. Barbero, M.; Merletti, R.; Rainoldi, A. Atlas of Muscle Innervation Zones; Springer: Milan, Italy, 2012; ISBN 978-88-470-2462-5.

220. Harkonen, R.; Piirtomaa, M.; Alaranta, H. Grip strength and hand position of the dynamometer in 204 finnish adults. J. Hand Surg.-Br. Eur. Vol. 1993, 18B, 129-132. [CrossRef]

221. Mathiowetz, V.; Kashman, N.; Volland, G.; Weber, K.; Dowe, M.; Rogers, S. Grip and pinch strength-Normative data for adults. Arch. Phys. Med. Rehabil. 1985, 66, 69-74. [PubMed]

222. van Tulder, M.; Furlan, A.; Bombardier, C.; Bouter, L. Editorial Board of the Cochrane Collaboration Back Review Group. Updated method guidelines for systematic reviews in the cochrane collaboration back review group. Spine (Phila PA 1976) 2003, 28, 1290-1299. [CrossRef] [PubMed]

223. Lau, J.; Ioannidis, J.P.; Schmid, C.H. Quantitative synthesis in systematic reviews. Ann. Intern. Med. 1997, 127, 820-826. [CrossRef] [PubMed]

224. Higgins, J.P.; Green, S. (Eds.) Cochrane Handbook for Systematic Reviews of Intervention; John Wiley \& Sons, Ltd.: New York, NY, USA, 2009.

225. Kitchenham, B. Procedures for Performing Systematic Reviews; Joint Technical Report; Keele University Press: Edinburgh, UK, 2004.

(C) 2018 by the authors. Licensee MDPI, Basel, Switzerland. This article is an open access article distributed under the terms and conditions of the Creative Commons Attribution (CC BY) license (http://creativecommons.org/licenses/by/4.0/). 